\title{
Berberská etnomedicína: Léčivé rostliny a jejich využití ve Vysokém Atlasu v Maroku
}

\author{
Barbora Půtová \\ Ústav etnologie, Filozofická fakulta, Univerzita Karlova, nám. Jana Palacha 2, 11638 Praha 1, Česká republika
}

Do redakce doručeno 8. záŕí 2017; k publikaci přijato 13. listopadu 2017

\section{BERBER ETHNOMEDICINE: HEALING HERBS AND THEIR USE IN THE HIGH ATLAS IN MOROCCO}

\begin{abstract}
In the paper I discuss the conceptualization of the medical pluralism in Morocco. I pay special attention to Berber ethnomedicine in the High Atlas, making use of my field research carried out in 2014 and 2017. My conclusions and findings are based on studying Moroccan health systems in a broader developmental and cultural context. In the first part of my paper I define ethnomedicine and biomedicine in Morocco. In the following part I describe Berber ethnomedicine with emphasis on the High Atlas, focusing on the role of traditional women healers, the main principles of their treatment methods and use of healing herbs. On a more general note I describe healing herbs, their effects and how they are used in the High Atlas. In the final part of my paper I present the traditional model of sustainable use of natural resources and the current development of unsustainable use of natural resources that may have impact on Berber ethnomedicine and even result to the extinction of medical pluralism in Morocco.
\end{abstract}

KEY WORDS ethnomedicine; biomedicine; healing herbs; Berbers; High Atlas

\begin{abstract}
ABSTRAKT Ve studii se věnuji konceptualizaci medicínského pluralismu v Maroku. Pozornost kladu zejména na berberskou etnomedicínu v pohoří Vysokého Atlasu na základě vlastního terénního výzkumu realizovaného v průběhu let 2014 až 2017. Moje vlastní závěry a poznatky se opírají o studium marockých medicínských systémů v širším vývojovém a kulturním kontextu. V první části studie se zaměřuji na vymezení etnomedicíny a biomedicíny v Maroku. V další části přibližuji berberskou etnomedicínu s důrazem na oblast Vysokého Atlasu, kde charakterizuji roli léčitelek, jejich metody léčby a způsoby využití léčivých rostlin. $\mathrm{V}$ obecné rovině pak provádím deskripci léčivých rostlin, jejich účinků a způsobů využití ve zkoumané oblasti. V poslední části studie představuji tradiční model udržitelného využití př́rodních zdrojů a aktuální vývoj neudržitelného využití přírodních zdrojů, které se mohou projevovat ve změně berberské etnomedicíny, ale současně také vést až k zániku pluralitního medicínského systému v Maroku.
\end{abstract}

KLÍČOVÁ SLOVA etnomedicína; biomedicína; léčivé rostliny; Berbeři; Vysoký Atlas

\section{ÚVOD DO MEDICÍNSKÉHO PLURALISMU V MAROKU}

Území dnešního Maroka se nachází na křižovatkách starých obchodních cest. Jeho současná populace se zformovala $\mathrm{v}$ průběhu několika migračních vln, které sem směřovaly z oblasti jižní Evropy, Arábie a subsaharské Afriky a postupně se mísily s původním severoafrickým obyvatelstvem. Čtyři horská pásma - Ríf, Střední Atlas, Vysoký Atlas a AntiAtlas -, se rozprostírají kolem pobřežních a vnitrozemských rovin, jež je oddělují od saharské pouště. Tato topografie a různorodost biomů podporuje lokální biodiverzitu místních ekosystémů, která se promítá také do diverzity sociálních skupin a ve svých důsledcích ovlivňuje i lokální medicínský pluralismus. Mnoho rostlin je zde tradičně a kontinuálně užíváno pro své léčivé nebo aromatické vlastnosti berberskými komunitami (Lagnaoui 1999; Msanda - El Aboudi - Peltier 2005; Ghanmi et al. 2011). Berberskou medicínu založenou na fytoterapii a animismu $\mathrm{v}$ Maroku doplňuje arabskoislámská prorocká medicína a západní biomedicína. Marocký 
medicínský pluralismus se rozvíjel nejen pod vlivem lokálních demografických, ekonomických a ekologických faktorů, ale také v důsledku historických a sociokulturních změn, jejichž součástí byl př́íchod Berberů do severní Afriky, odkaz antické civilizace, islámská arabská expanze a francouzský i španělský protektorát (Baer 2004; Půtová 2016).

\section{MEDICÍNSKÝ PLURALISMUS OPTIKOU ETNOMEDICÍNY A BIOMEDICÍNY V MAROKU}

Marocká etnomedicína představuje kognitivní systém, který zahrnuje znalosti, dovednosti a praktiky založené na přesvědčení, viŕ̌e a zkušenostech berberských komunit, jež se používají $\mathrm{k}$ udržení zdraví, prevenci, diagnostice a léčbě tělesných a duševních nemocí (Kleinman 1978; Sullivan 1989). Jednou ze silných stránek berberské etnomedicíny, dobře zakořeněné v lokální kultuře, je její charakter praktického umění, který podporuje blízký vztah mezi pacientem a léčitelem, rodinou a komunitou. Zásadní úlohu hrají príbuzenské a sociální vztahy pacienta, které také určují a ovlivňují průběh léčby. Berberská etnomedicína integruje magické, animistické nebo náboženské prvky (Turner 1967; Dow 1986). Stanovení př́čin nemoci a diagnózy zahrnuje jak přirozené, tak nadpřirozené faktory způsobující onemocnění, jako jsou například boží trest, posedlost, působení zlého ducha nebo zlého oka. Nemoci jsou na základě nadpřirozené kauzality členěny na nemoci způsobené duchem (posedlost džinem), člověkem (čarodějnictví) a bohem (přirozená nemoc). Tradiční léčba využívá znalosti fytoterapie, kdy je léčivo aplikováno hlavně perorálně a lokálně. Etnomedicína dosahuje vynikajících výsledků v léčbě široké škály běžných onemocnění (trávicí ústrojí, uši, nos a krk, plíce, průdušky a kůže), (Greenwood 1981; Bellakhdar 1997).

Nemoci, u nichž byly diagnostikovány přirozené př́íciny a mohou být fyzické nebo patologické povahy, jako např́klad syfilis nebo tuberkulóza, častěji rituálně ošetřuuí svatí muži (chorfa, pl. cherif) nebo duchovní léčitelé (fqih, pl. fuqaha). Oproti tomu nemoci, jejichž vznik je přičítán nadpřirozeným příčinám, např́ílad deprese, epilepsie a onemocnění postrádající ekvivalent $\mathrm{v}$ západní biomedicíně, ošetřují léčivými rostlinami bylinkáři (attar), bylinkářky (ashshaba) a porodní báby (dayat nebo qablat), (Janzen - Prins 1981; Stillman 1982; Feierman - Janzen 1992; Kapchan 1996; Helman 2008; Mateo Dieste 2013; Altorki 2015). „Pokud jde o léčivé byliny a směsi, attar funguje jako tradiční lékárník i lidový léćitel, který často předepisuje byliny a směsi pro takové onemocnèní, jako jsou horečky, střevní potiže, bolesti hlavy a nespavost. "(Tabbaa - Mervin 2014, 61) Léčitel i léčitelka jsou v městských, vesnických a horských oblastech berberské Afriky rovněž považováni za kompetentní $\mathrm{k}$ tomu, aby prováděli některé fyzické lékařské zákroky, jako jsou porodnické intervence, narovnání zlomenin nebo trepanace lebky. Mnohá drobná onemocnění se však léćí doma pomocí bylinných prrípravků na základě znalosti léčivých rostlin rozšiřrené ve venkovském i v městském Maroku. Vyšší autoritu poživá léčitel, zatímco léčitelka je více sociálně marginalizována, nebot ženská moc je vnímána jako "destruktivní prvek v muslimském sociálním řádu“ (Mernissi 1987, 33). Př̀i léčbě onemocnění, u nichž se př̀edpokládá, že byly způsobeny vlivem nadprirozených sil, tradiční léčitelky (ferragga, pl. ferraggat) jako hlavní léčbu používají rostliny (Bakker 1992; Teixidor-Toneu et al. 2017).

Vedle etnomedicíny se pod vlivem evropského lékařství v Maroku prosadila také západní biomedicína, která je založená na vědeckých poznatcích a léčebných postupech reprezentovaných osobou lékaře nebo lékařky. Tento model biomedicíny souvisí s vědeckým redukcionismem a profesní specializací, což se promítá do kategorie „uzdravení“, která je chápána jako výsledek odstranění a vyléčení nemoci. Profesně specializovaná západní biomedicína při léčbě lidského těla postupuje od jednoho fenoménu $\mathrm{k}$ druhému a předem předpokládá jejich oddělitelnost. Odděluje mysl od těla a jednotlivosti od celku. Taxonomicky redukuje onemocnění do základních prvků, ošetření do měřitelných částí, medicínskou praxi do několika oborů a vytrhuje pacienty ze sociálních vztahů a kultury (Kleinman 1988; Gaines - Davis-Floyd 2004). Západní biomedicína proměnila tradiční klasifikace nemocí (folktaxonomie), způsob diagnostiky, léčebné postupy a užitá léčiva. Tento model lékařství je dědictvím koloniální vlády v Maroku, jež vedle dominantního biologického (funkčního) chápání nemoci představuje „boj o nadřazenost jednoho typu znalostí a jednoho modelu diagnózy nad řadou dalšich" (Jones 2004, 704).

K hlavním atributům a projevům nadřazenosti západní biomedicíny nad etnomedicínou patř́i důraz na exaktnost, objektivitu a progresivní charakter užívaných technologií. Státem podporovaná biomedicína získala výraznou mocenskou pozici přidělením monopolu na poskytování zdravotních služeb (veřejné a soukromé nemocnice, zdravotní střediska), který stát zakotvil ve své legislativě (Parusniková 2000; Baer 2004). Biomedicínský př́stup ke zdraví a nemoci založený na exaktní vědě je jedním ze zásadních projevů moderní biomoci, jež představuje způsob vládnutí a administraci moderní populace (Slepičková - Šlesingerová - Šmídová 2012). Mnoho obyvatel větších měst $\mathrm{v}$ Maroku s vyšším socioekonomickým postavením se hlásí $\mathrm{k}$ evropskému biomedicínskému modelu zdraví a popírá existenci jakékoli jiné marocké medicínské tradice. Dokonce biomedicínu vnímají jako symbol modernity, pozitivního vývoje a žádoucí globalizace. Naopak jiní obyvatelé Maroka revalorizují nebo přinejmenším respektují tradiční léčbu a pouze utilitárně akceptují výhody vyplývající z biomedicíny (Baer - Singer - Susser 1997). „Někteř́ vyhledávají tradiční medicínu jako doplněk moderní mediciny, zatímco jiní, kteři jsou bud' frustrovaní chemickými předpisy, které mají nepríijemné vedlejší účinky, nebo si je prostě nemohou dovolit, spoléhají téměr výhradně na tradiční medicínu." (Tabbaa - Mervin 2014, 61) Napříc sociálními kategoriemi dochází ke komplementaritě a pluralismu medicínských př́stupů, což souvisí zejména s požadavky na anonymitu pacienta a jeho nemoci, nižšími finančními náklady za léčbu nebo $s$ touhou zvolit tradiční metodu i za předpokladu nejistého účinku nebo délky léčby (Mateo Dieste 2013). 


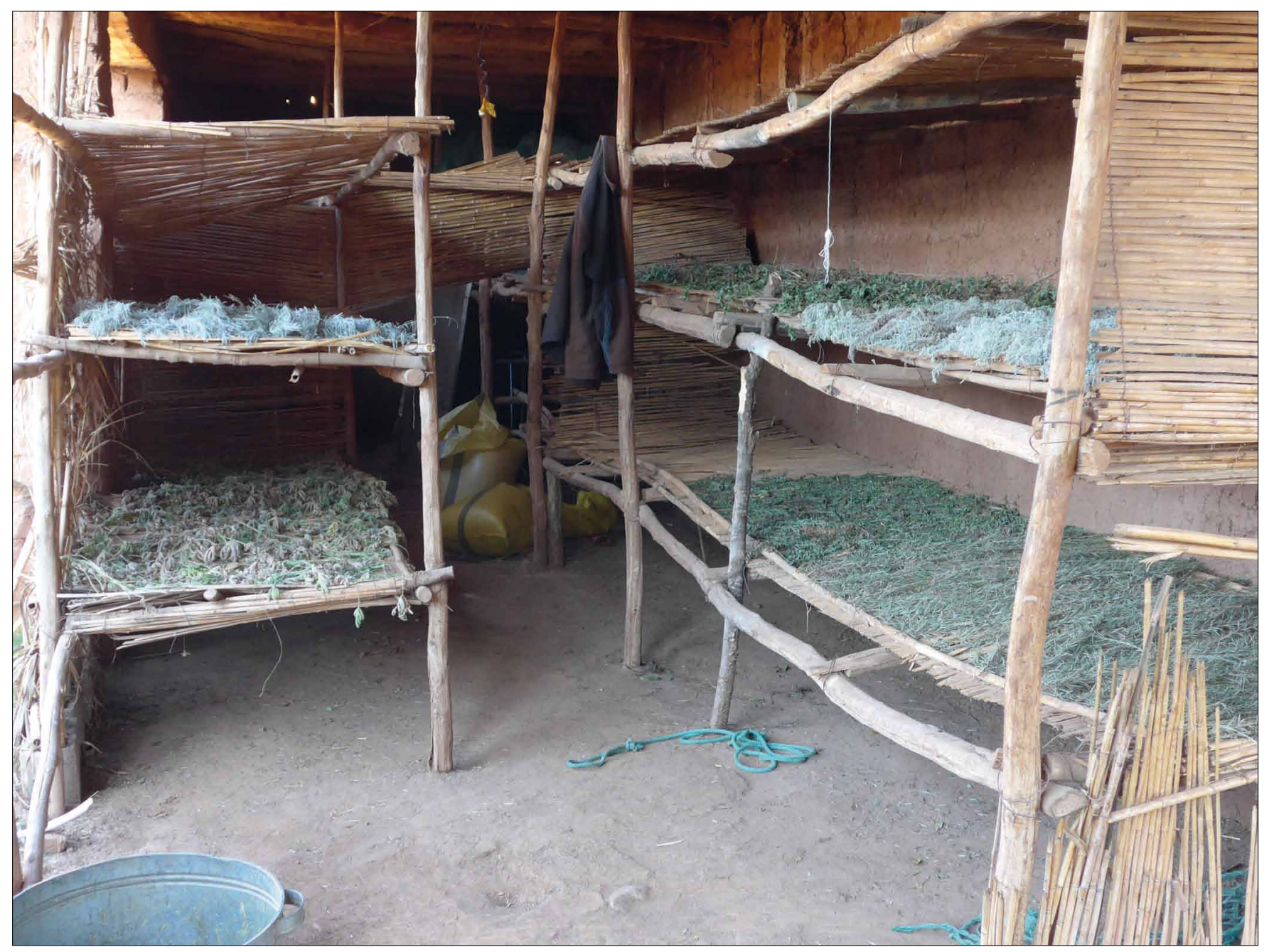

Z bylin, které jsou sušeny v domácnostech, se připravuje léčivo pro nemocné př́islušníky berberské rodiny.

Koloniální vláda v době francouzského protektorátu a implementování evropské biomedicíny vytvořily přetrvávající právní a strukturální nerovnováhu, stejně jako zakořenění asymetrie mezi Afrikou a Západem - Marokem a Francií - a mezi bohatými a chudými obyvateli Maroka. To vyústilo v narůstající sociální a ekonomické rozdíly dané nerovnoměrným přístupem k materiálním zdrojům, vzdělání a moci a ve vyostření rozdílu mezi marockým městem a vesnicí. Biomedicínské zdravotní služby nejsou v Maroku dostupné pro celou populaci (Kim 2000). Přibližně $50 \%$ obyvatel žije ve venkovských a horských oblastech. Etnomedicína je proto vyhledávána nejen $\mathrm{z}$ důvodu své účinnosti nebo selhání západní biomedicíny, ale také $\mathrm{z}$ nedostatku moderních léčebných alternativ, vysokých nákladů, velké vzdálenosti veřejných zdravotnických zarízení nebo lokálních kulturních preferencí. Urbánní povaha moderní medicíny je dalším z faktorů, který působí ve prospěch etnomedicíny. Lokální léčitelé a léčitelky totiž ve venkovských oblastech péči poskytují i v domácnostech pacientů. Velmi důležitou roli při výběru lékařské péče sehrávají zejména finanční možnosti, včetně schopnosti splácet minimální pojistné plnění. Léčitelé a léčitelky zpravidla ponechávají výši poplatků na uvážení pacienta a konzultace se vyplácejí v naturáliích (Bannerman - Burton - Wen-Chieh 1983; Bellakhdar 1989; Whyte - Geest - Hardon 2007).

Medicínský pluralismus a „medicínský dialog může tedy sloužit jako okno, jehož prostřednictvím lze pozorovat sociální procesy" (Crandon 1986, 463), které ovlivňují výběr z několika alternativ léčby. Vždy záleží na typu nemoci, symptomech, sociálních okolnostech jejího vzniku a na její interpretaci ze strany léčitele a pacienta. $\mathrm{V}$ intencích biomedicínské tradice bolest žaludku lékař vysvětlí jako důsledek požití prríliš mnoho jídla nebo projev infekčního onemocnění. Podle etnomedicíny stejné obtíže lokální léčitel popíše jako humorální nerovnováhu nebo posedlost zlým duchem. Ačkoliv lze etnomedicínu a biomedicínu nahlížet jako kompetitivní medicínské přístupy, v Maroku jednotlivé terapeutické systémy vzájemně koexistují a tím potvrzují i synkretický charakter marockého léčitelství. Nemocný Maročan může na vesnici vyhledat lékařskou pomoc akreditovaného lékaře, navštívit lokálního léčitele nebo využít lokální etnobotanické znalosti a domácí bylinné léčebné prostředky. Skoro každá rodina má alespoň jednoho staršího člena domácnosti, nejčastěji jednoho z ro- 
dičů nebo prarodičů, který kromě moudrosti odvozené ze zkušenosti disponuje znalostmi léčivých rostlin. Znalosti léčivých rostlin a jejich užití jsou obvykle přenášeny z generace na generaci, avšak dnes kontinuální generační přenos ztrácí na významu $z$ důvodů pracovní migrace, opuštění tradičních pracovních rolí, modernizací marocké kultury nebo proměny sociálních vztahů. Vzestup ortodoxní formy islámu a povinné školní docházky se podílí na generační kulturní změně. Školní docházka snižuje čas k získání znalostí o léčbě nebo rostlinách v prostředí domova a přírody. Současně se jedná o nový diskurs, který tradiční znalosti komunity vnímá jako regresivní trend. To ve svém důsledku posiluje nadřazenost západní biomedicíny a vede k pozvolné změně lokálního medicínského paradigmatu (Terem 2014).

\section{ETNOMEDICÍNA VE VYSOKÉM ATLASU: TRADIČNÍ LÉČITELKY A HLAVNÍ PRINCIPY JEJICH LÉČBY}

Ve venkovských oblastech Maroka, zejména v pohoří Vysokého Atlasu, působí tradiční léčitelky ferraggat. Jedná se obvykle o starší ženy, které léčí nemoci vyvolané nadpřirozenými přičinami a používají jako hlavní princip léčby aromatické a léčivé rostliny. Ferragga údajně slouží jako nádoba, jejímž prostřednictvím Alláh uzdravuje. Všechna uzdravení prostřednictvím ferragga jsou proto spojována s boží vůlí. Specializují se na léčbu a onemocnění žen a zejména dětí. V léčbě používají směs léčivých rostlin frigg. Označení frigg se také vztahuje k samotné léčbě, jež zahrnuje rituální a etnofarmakologická ošetření (Moerman - Jonas 2002). Ferraggat jsou nositelky baraky, jež je vnímána jako „tajemná zázračná síla, která je považována za požehnání od Boha." (Westermarck 1926, 35) Baraka se podle víry místních domorodců nachází na pomezí ctnosti, duchovního vlivu a moci. V současnosti se ferraggat objevují i v Marrákeši, kde mohou být nižšího věku. Zde je však patrný posun směrem $\mathrm{k}$ profesionalizaci, jejíz součástí je časový rozvrh a fixní ceny za provedené léčitelské služby (Pordié - Simon 2013). Na venkově udržují ferraggat osobní vztahy se svými pacienty, žijí zpravidla v jejich blízkosti a nejsou časově omezeny, což posiluje účinnost jejich léčby. Léčitelky pracují v režimu označovaném jako fi sabilillah, bez očekávání náhrady, zpravidla na základě daru. Venkovské matky obvykle vyhledávají ferraggat, když jsou jejich děti nemocné. $\mathrm{V}$ mnoha prípadech jsou totiž jedinou dostupnou zdravotní péčí. Ferraggat ale také vyhledávají matky, u jejichž dětí poskytnutá biomedicínská léčba selhala.

Ferraggat léčí zejména tři typy onemocnění, označované taqait, taumist a iqdi, které se projevují př́iznaky podobné ušní infekci, angíně a gastroenteritidě. Kromě toho léčí onemocnění spojené s fyzickým vývojem lidského těla, muskuloskeletální problémy a některá gynekologická onemocnění žen. Dítě postižené taqait odmítá kojení, obtížně polyká, cítí bolest v uších nebo zvrací. Diagnóza se obvykle provádí kontrolou jazyka dítěte palcem. Dítě má taqait, pokud ferragga nahmatá $\mathrm{v}$ ústech na patře malou kuličku, podobnou kukuřičnému zrnu. Taumist je považováno za fyzickou reakci na talismany,

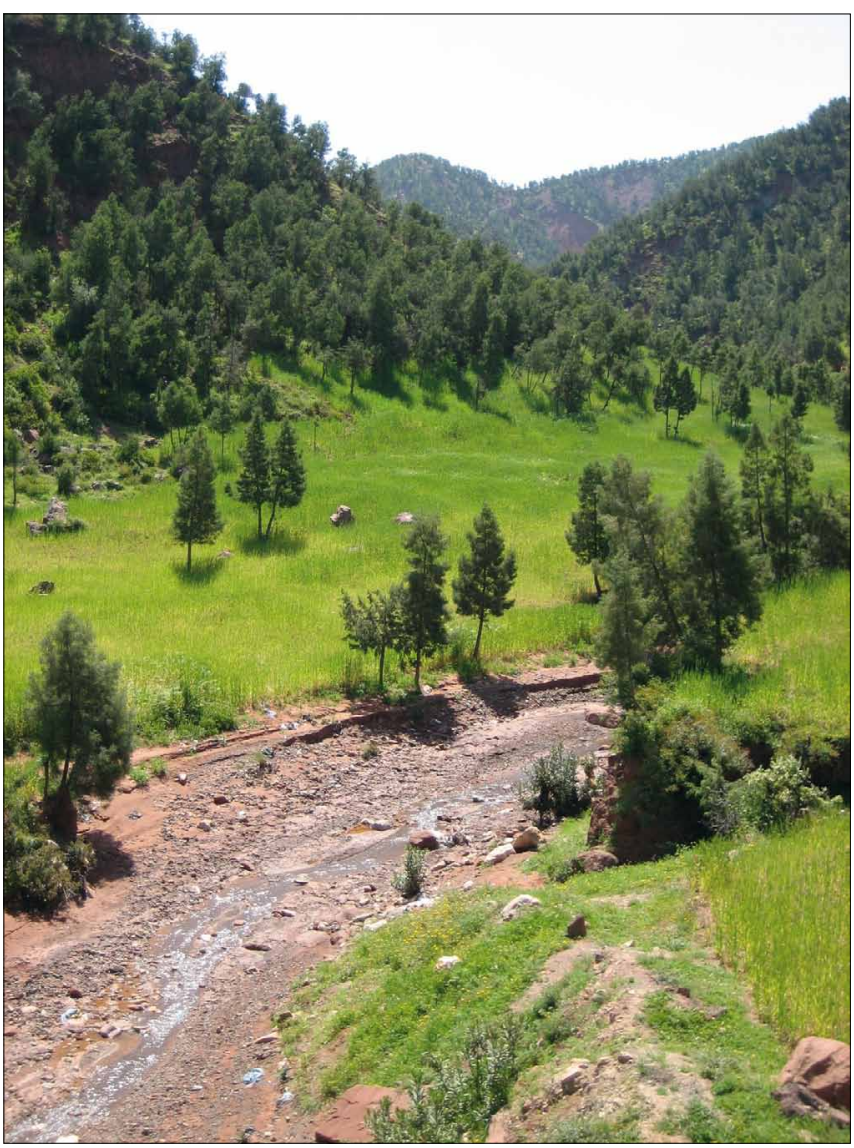

Většina ferraggat používá olej ze sandarakovníku článkovaného. Tato berberská túje pokrývá horské svahy Vysokého Atlasu.

které nosí obvykle ženy. Talismany mohou léčit nebo předcházet onemocnění, chránit před zlým okem nebo přinášet štěstí. Zpravidla je zhotovují duchovní léčitelé (fqih) z papírového svitku, na němž jsou napsány verše z koránu. Talismany obsahují sůl a semena harmaly mnohodílné (Peganum harmala). Mnohdy zahrnují i další rostliny, jako jsou koriandr setý (Coriandrum sativum), černucha setá (Nigella sativa), arnika montana (Ruta montana) a sandarakovník článkovaný (Tetraclinis articulata). Děti mohou pocitovat onemocnění taumist, pokud jsou v blízkosti osoby, která nosí talisman. Onemocnění doprovází příznaky sunken fontanela (měkké místo na temeni hlavy), rozšiřující se na čelo, letargie a dermatologické projevy, při nichž se objevuje kůže zelenkavé barvy. Postižení mohou trpět i průjmem, bolestí břicha a horečkou. Onemocnění iqdi doprovází zapáchající kůže, zvracení, průjem a odmítání kojení. Z perspektivy západní biomedicíny onemocnění taqait odpovídá symptomům ušní infekce a angíny, zatímco taumist a iqdi se podobají gastroenteritidě.

Ferragga zahajuje léčebné sezení pronášením bismillah, ve jménu Alláha, některé ferraggat sypou na dítě sůl. Na začátku sezení může být použito i vykuřování, $\mathrm{k}$ němuž slouží hořící suché stonky henovníku bílého (Lawsonia inermis) nebo jablečníku obecného (Marrubium vulgare), praktikované v blízkosti kojence kvưli inhalaci kouře. Onemocnění taqait, taumist a iqdi jsou sice diagnostikována jako různé 


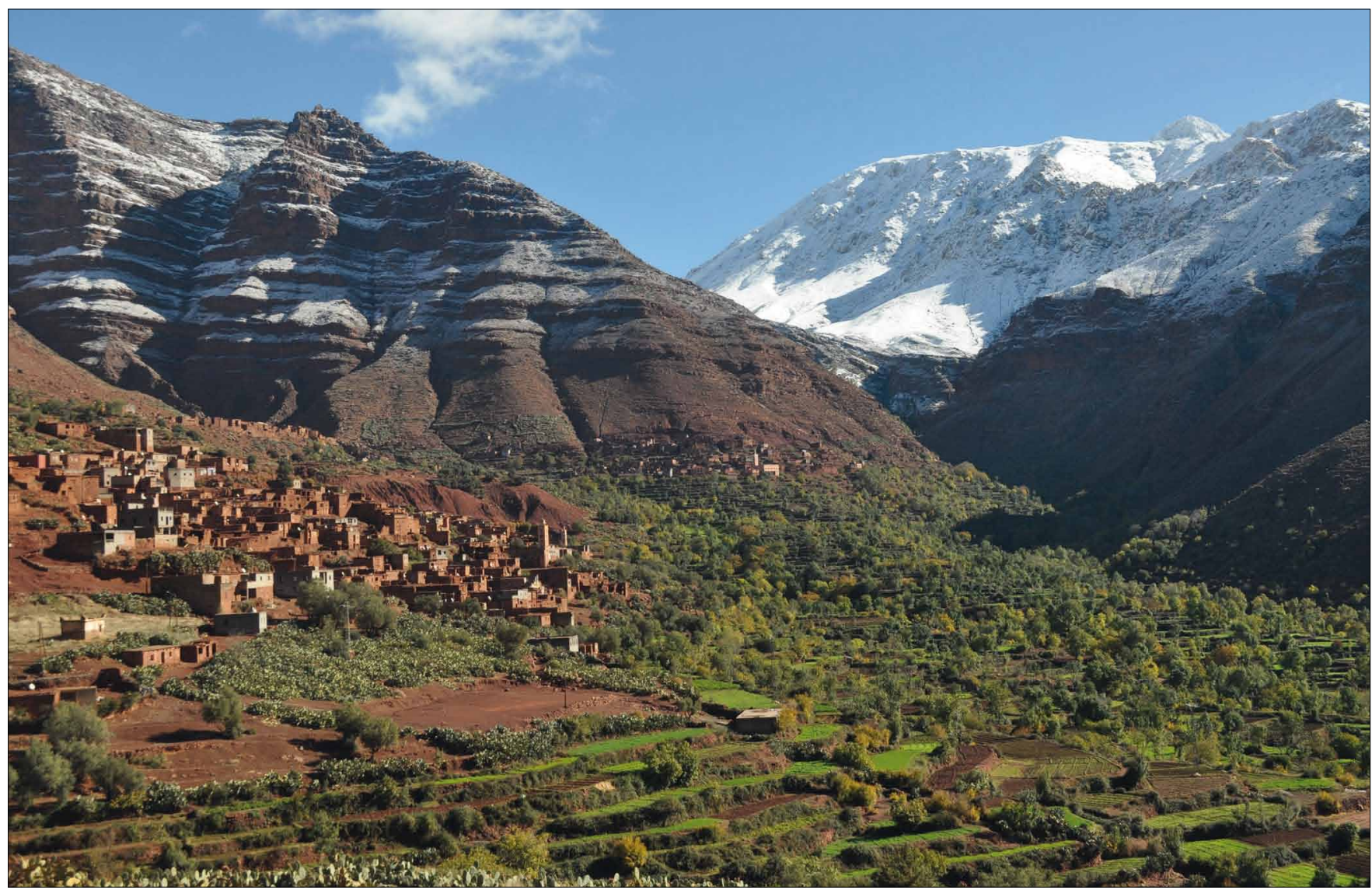

Terasovitá pole, na nichž rostou mnohé léčivé rostliny, obklopují vesnice Aguerd a Annamer v údolí Ourika ve Vysokém Atlasu.

nemoci, ale léčí se za pomoci bylin frigg. Jedná se o směs suchých rostlin, jež jsou rozemlety a smíchány s olivovým olejem. Venkovské ferraggat užívají mnoho rostlin, které rostou a jsou běžně dostupné ve Vysokém Atlasu, jako je merlík vonný (Dysphania ambrosioides), levandule zoubkatá (Lavandula dentata), kmín kořenný (Carum carvi), máta vonná (Mentha suaveolens), tymián (Thymus satureioides), marhaník obecný (Punica granatum), dobromysl obecná (Origanum vulgare L.), fenykl obecný (Foeniculum vulgare) nebo černucha setá (Nigella sativa). Směs se užívá $\mathrm{k}$ masáži těla dítěte, může být podávána také perorálně nebo v podobě kapek do uší a nosu. Většina ferraggat používá olej ze sandarakovníku článkovaného (Tetraclinis articulata) a $\mathrm{z}$ různých druhů jalovce (Juniperus), jako je jalovec červenoplodý (Juniperus oxycedrus) nebo jalovec kadidlový (Juniperus thurifera). Silně vonící olej je aplikován v oblasti nosu, spánků, zápěstí a na hlavu dítěte. Pomáhá vyčistit špatné vůně a ochraňuje dítě před dalším zápachem. Muskuloskeletální a vývojové problémy léčitelky ošetřují různými protahovacími cvičeními a důkladnou masáží za pomocí friggu, po němž následuje svázání, někdy za užití dřevěných desek jako nosičů. Metoda kauterizace je někdy aplikována k léčbě muskuloskeletálních problémů. Ferraggat používají hořící sušené stonky jablečníku obecného (Marrubium vulgare) k lehkému dotyku konkrétních části těla dítěte, zejména oblasti kloubů, břicha a zad.
Ferraggat mají odlišné postupy v užití léčivých rostlin. Léčitelky užívají k léčbě onemocnění desítky bylin a rostlin $\mathrm{v}$ různém poměru, směsi a kvalitě ingrediencí. Poměr zastoupených druhů bylin a rostlin ve friggu ovlivňuje, zdali ferraggat svou činnost vykonávají ve městech nebo na vesnicích. Druhově bohaté směsi jsou účinným prostředkem pro léčbu onemocnění z multifaktoriálních přičin. Správné dávkování a dobrá kvalita ingrediencí jsou považovány za klíč k úspěchu léčby. Některé ferraggat jsou ale přesvědčeny, že jejich fyzický dotek je pro léčbu důležitější než užití rostlin.

$\mathrm{V}$ minulosti se užívalo méně rostlin nebo se dokonce vůbec nepoužívaly. Začlenění rostlin do léčebné praxe nahrazuje tradiční rituální ošetření. $\mathrm{V}$ současnosti převažující důraz na užití léčivých bylin je důsledkem sociokulturní změny a substitucí rituálního ošetření, $v$ němž se používala ovčí vlna a krev ze Svátku obětování (íd al-adhá). Tato proměna původně rituálně orientované etnomedicíny je důsledkem rostoucího vlivu ortodoxního islámu a státem podporované modernizace v oblasti zdravotnictví a školství. Léčivé rostliny a byliny ovšem i nadále hrají roli při legalizaci praxe léčitelek. Ty na jedné straně uchovávají nativní léčitelské folktaxonomie a léčebné praktiky, ale na straně druhé přizpůsobují svoji léčbu tomu, aby odpovídala představám islámského náboženství a dopadu modernizace na tradiční berberskou kulturu. Znalosti o léčivých rostlinách použivaných ve friggu jsou přená- 


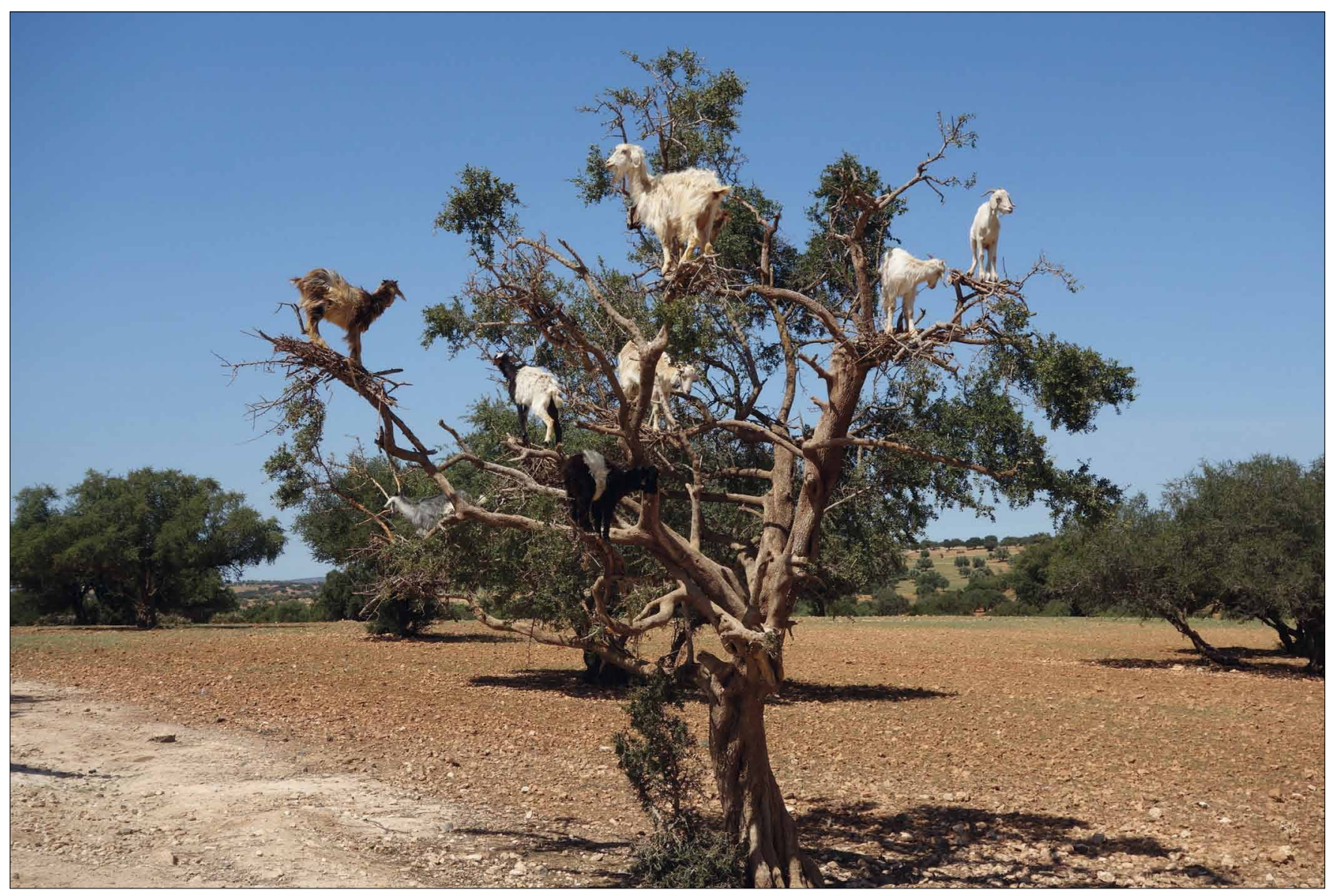

Ve Vysokém Atlasu se v korunách stromu argánie trnité pasou kozy.

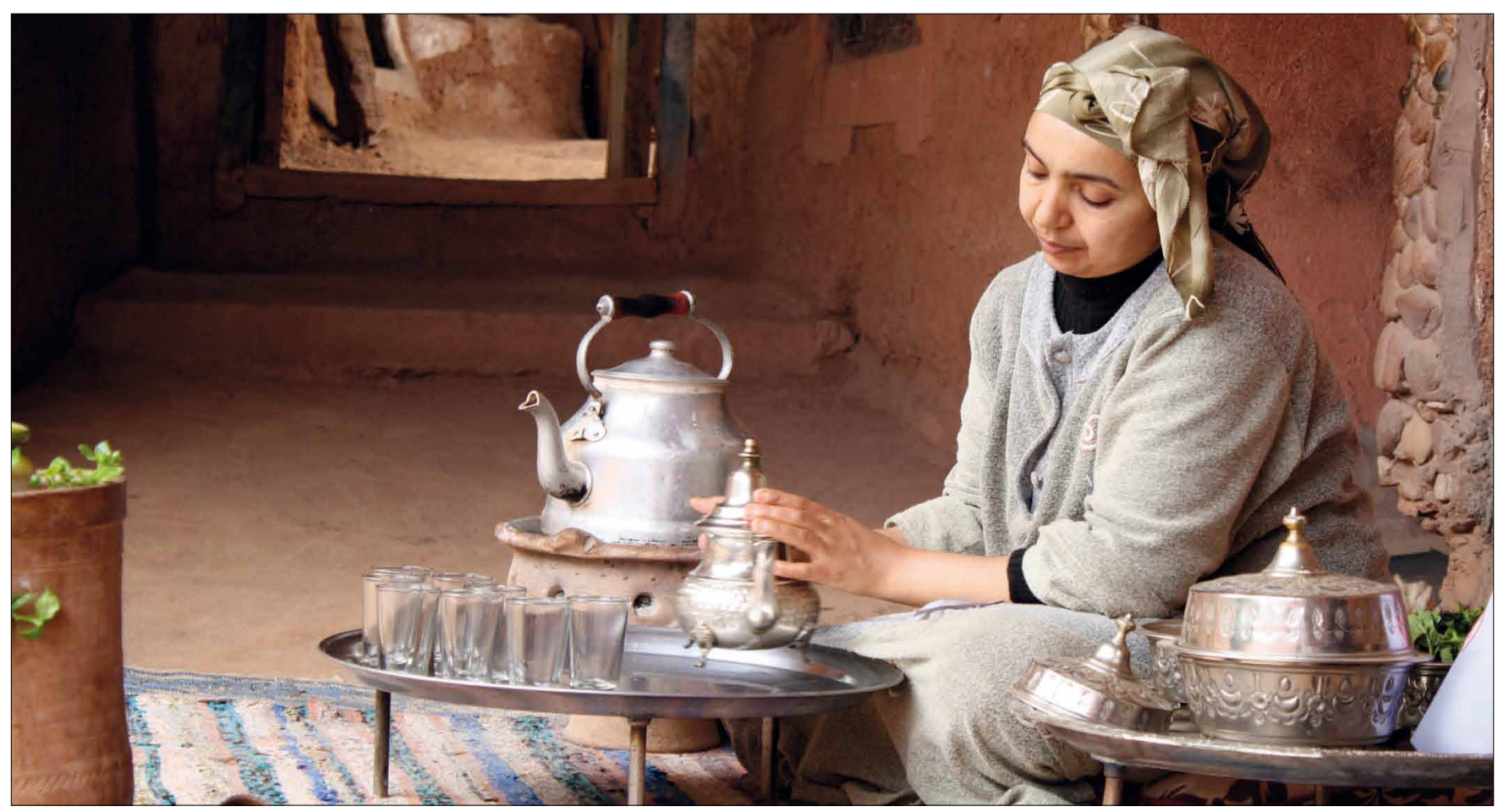

Tradiční berberský čaj, připravovaný z extraktu z máty a zeleného čaje, představuje osvěžující nápoj. 
šeny orálně a většina ferraggat se je naučila od svých matek, babiček nebo tchýní (vertikální přenos). Některé léčitelky si dovednosti osvojily od jiné ferraggaty (horizontální přenos). Většina ferraggat se začala učit léčitelské praxi, až když vznikla akutní potřeba nové léčitelky, například po smrti vesnické ferragga. Na rozdíl od jiných lidových poznatků o léčivých rostlinách, které jsou předávány kontinuálně od dětství, $\mathrm{k}$ učení friggu dochází u žen středního věku. Ve skutečnosti neexistuje žádná systematická výuka, jak se stát ferragga kromě několika málo předpokladů, jako jsou znalosti léčivých rostlin, umění jejich aplikace na různé typy onemocnění a diagnostické schopnosti.

\section{LÉČIVÉ ROSTLINY A JEJICH UŽITÍ V ETNOMEDICÍNĚ VE VYSOKÉM ATLASU}

Léčivé rostliny jsou na území Maroka tradičně uživány jako prostředek lokální berberské etnomedicíny. Znalosti léčivých $\mathrm{a}$ aromatických rostlin jsou sdíleny a předávány $\mathrm{v}$ rámci komunity. Přenos vědomostí o léčivých bylinách zajištuje širší rodina, jež zahrnuje prarodiče, rodiče, sestry, tety a strýce. Poznatky o rostlinách jsou společné mužům i ženám, ovšem kontext jejich distribuce se odlišuje. Obecně však platí, že ženy používají mnohem více bylin než muži. V domácnosti se dívky učí hlavně od matky, prarodičủ, zejména pak babičky, nebo samostatně. Tyto znalosti jsou získávány sledováním dalších žen, které sbírají léčivé rostliny na terasovitých polích, $\mathrm{u}$ řeky nebo $\mathrm{v}$ horách, ukládají rostliny $\mathrm{v}$ domě a prripravují léčivo pro nemocné příslušníky rodiny. Dívky se učí i od léčitelek nebo léčitelů, přátel a starších členů vesnické komunity, v současnosti i z televizních pořadů. Chlapci získávají znalosti o léčebném účinku rostlin od matky, v menší míře také od prarodičů. Učí se i od léčitelů, práatel ve vesnici a $z$ literatury. Většina mužů získává etnobotanické znalosti při práci v horách, v lese nebo na terasovitých polích. Důležité je zapojení do tradičních aktivit, $v$ jejichž průběhu dochází ke sběru rostlin. Děti např́klad doprovází rodiče na terasovitá pole nebo sbírají pícninu pro dobytek v horách. V současné době je přenos znalostí rostlin a jiných tradičních aktivit velmi ohrožený, protože komunita je stále více vystavena exogenním vlivům západní civilizace (Sijelmassi 1990; Bellakhdar 1997; Génin - Simenel 2011).

Marocká flóra zahrnuje na více než 7000 druhů a poddruhů rostlin, $\mathrm{z}$ nichž nejméně 500 druhů zastupují aromatické a léčivé rostliny (Sijelmassi 1990, Bellakhar 1997, Hmamouchi 1999, Benabid 2000). Léčivou flóru ve Vysokém Atlasu reprezentují zejména čeledi hluchavkovité (Lamiaceae), hvězdnicovité (Asteraceae), miříkovité (Apiaceae), kyprejovité (Lythraceae), kosatcovité (Iridaceae), mořenovité (Rubiaceae), jitrocelovité (Plantaginaceae), cypřišovité (Cupressaceae), sporýšovité (Verbenaceae) nebo olivovníkovité (Oleaceae), (Hsein - Kahouadji 2007; Nassif - Tanji 2013). Vysoce rozšířené jsou endemické rostliny jako tymián (Thymus satureioides), levandule zoubkatá (Lavandula dentata) a šalvěj (Salvia aucheri). K další vyhledávaným léčivým a aromatickým rost- linám patři rozmarýn lékařský (Rosemary officinalis), pelyněk (Artemisia herbaalba Asso), merlík vonný (Dysphania ambrosioides $L$.), cist šalvějolistý (Cistus salviifolius L.), koulenka křovitá (Globularia alypum L.), jablečník obecný (Marrubium vulgare L.), koriandr setý (Coriandrum sativum), marhaník obecný (Punica granatum), fenykl obecný (Foeniculum vulgare), oman (Inula montana L.), kosatec německý (Iris germanica L.), citrónová verbena (Lippia citriodora Kunth), mořena cizí (Rubia peregrina L.), polej obecná (Mentha pulegium L.), sandarakovník článkovaný (Tetraclinis articulata), černucha setá (Nigella sativa), divizna laločnatá (Verbascum sinuatum), pryšec pryskyřičný (Euphorbia resinifera), argánie trnitá (Argania spinosa L. Skeel), cypřiš vždyzelený (Cupressus atlantica), jalovec fénický (Juniperus phoenicea), topol osika (Populus tremula), olivovník evropský (Olea europaea), jasan úzkolistý (Fraxinus xanthroxyloides), dub cesmínovitý (Quercus rotundifolia), jedle marocká (Abies maroccanai), borovice halepská (Pinus halepensis) nebo zimostráz (Buxus balerica), (Sijelmassi 1990; Maselli 1996; Bellakhdar 1997; Fennane Rejdali 2016).

Nejčastěji používanou rostlinnou složkou pro léčení je list rostliny, dále semena, plody, podzemní části (kořen, cibule nebo hlíza), kůra a pryskyřice. Vysoká míra využití listů může být vysvětlena jak jejich dostupností, tak skutečností, že listy jsou hlavními fotosyntetickými orgány. Listy rostlin kumulují inuliny, tř́isloviny a jiné alkaloidy, které jsou zodpovědné za jejich léčebné vlastnosti a vysvětlují jejich široké použití (Parada et al. 2009). Z důvodu synergických účinků léčebných vlastností se rostlinné části různých druhů rostlin užívají také v podobě směsi, do níž je jako rozpouštědlo nejčastěji přidávána voda, př́padně med, olivový olej, mléko nebo čaj (Abouri et al. 2012; Jamila - Mostafa 2014). Léčivé rostliny se převážně připravují jako nálev (čaj), odvar nebo macerát, dále v podobě prášku, tonika a esenciálního oleje. Lokální aplikace je možná formou kataplazmy nebo frikce. V některých případech je zvolena i inhalační technika pomocí kouře nebo horkého vzduchu s léčivou esencí bylin, jako je například máta vonná (Mentha suaveolens).

Rostliny jsou sklízeny nejenom pro léčivo, nýbrž i jako prostředek konzervace nebo ochucení potravin, přísada kosmetických prrípravků nebo k extrahování esenciálního oleje (silice). Některé části půdy s výskytem léčivých rostlin jsou využívány jako pastviny nebo jsou vybrané rostliny sbírány jako pícnina. Léčivé rostliny ve Vysokém Atlasu jsou snadno dostupné, vykazují zde nízký stupeň toxických látek, jsou bez výrazných vedlejších účinků i při dlouhodobé konzumaci a bez rizika rezistence na extrakty a přírodní látky (laxativa, cikatrizanty, cholagoga nebo revulsiva). Mnoho místních druhů léčivých rostlin se tradičně používá na více onemocnění. Některé druhy se také aplikují jako antiseptikum k dezinfekci kůže (bradavice, hemostatika a abscesy). Léčivé rostliny jsou užívány na gastrointestinální poruchy, nachlazení a angínu, onemocnění dýchacích cest, bolesti hlavy, dermatologické problémy, diabetes, kardiovaskulární onemocnění, onemocnění jater nebo infekci močových cest (Bellakhdar 1997; Ziyyat et al. 1997; Bnouham et al. 2012). 


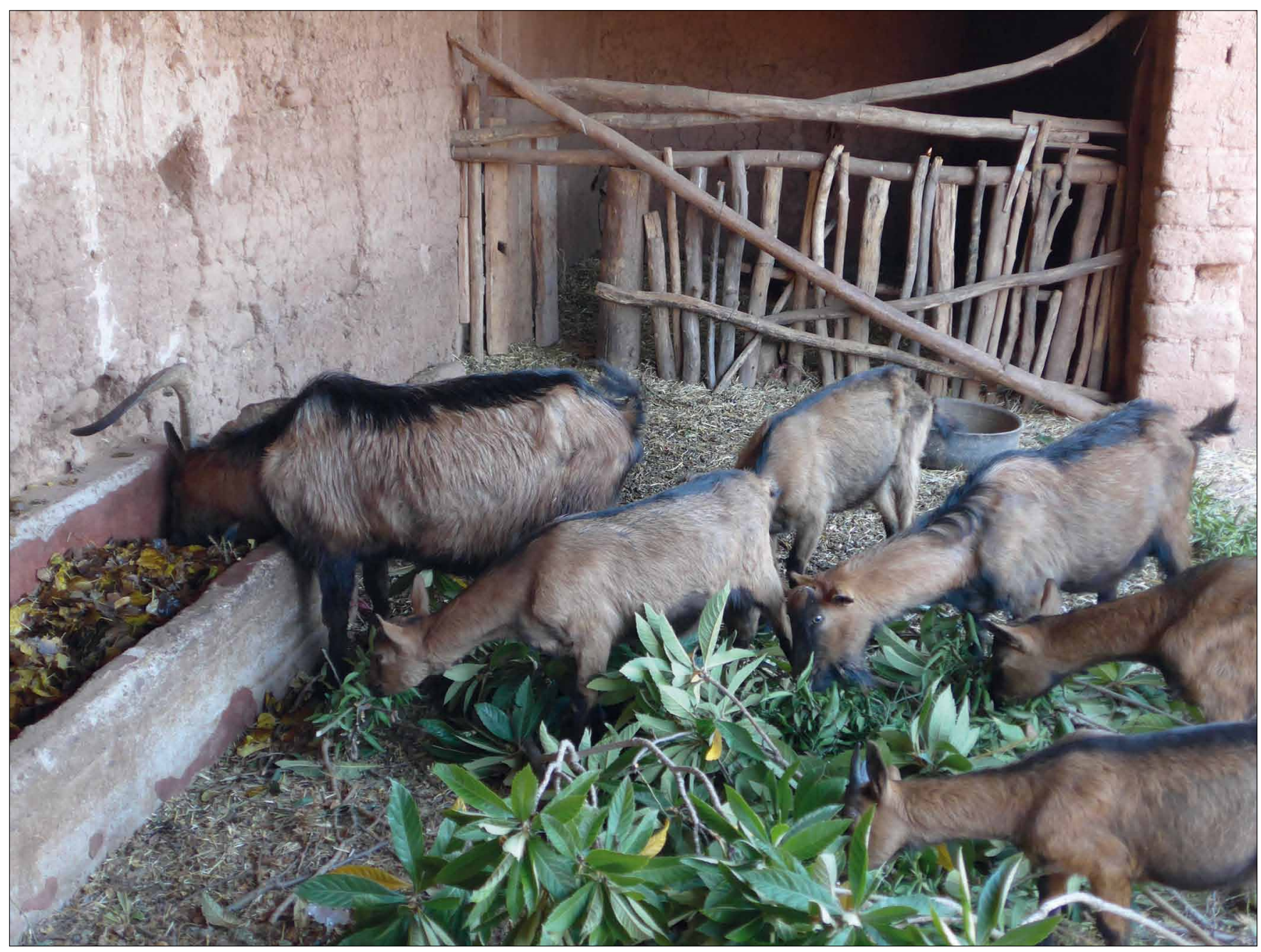

Některé léčivé rostliny tvoří pícninu pro kozy v pohoří Vysokého Atlasu.

\section{LÉČIVÉ ÚČINKY A TYPOLOGIE VYBRANÝCH LÉČIVÝCH ROSTLIN VE VYSOKÉM ATLASU}

Vysoce rozšířené ve Vysokém Atlasu jsou rostliny z čeledi hluchavkovitých, k nimž patř́i tymián, levandule zoubkatá, máta vonná, šalvěj, polej obecný a jablečník obecný. Tymián představuje jedno z nejsilnějších rostlinných antibiotik. V pohoří Vysokého Atlasu je sbírán a užíván pravidelně jako nálev během období sklizně (od května do července) nebo v sušené formě mimo období sklizně. Obecně je tymián aplikován při léčbě žaludečních potíží, zánětů horních a dolních cest dýchacích a kožních onemocněních. Tymián má totiž silné antioxidační, expektorační, spasmolytické, antispazmodické, antiseptické a desinfekční vlastnosti, proto působí na nachlazení, chřipku a sinusitidu, bronchitidu v akutních a chronických formách nebo i tuberkulózu (Zarzuelo - Crespo 2002). Dále se jeho léčivé účinky vztahují na trávicí a respirační obtíže, koliky, fermentace, gastritidu a infekci hrdla a úst (Bellakhdar 1997). Tymián je vyhledáván pro pozitivní účinky a stimulační vlastnosti v léčbě deprese, úzkosti a nespavosti. Jeho lokál- ní aplikace ve správném zředění urychluje hojení ran a kožní zanícení. Z tymiánu je extrahován olej, který se vyznačuje antibakteriálními vlastnostmi. Vzhledem k přítomnosti fenolických látek vykazuje tymiánový olej přímý inhibiční účinek na patogenní kmeny bakterií (Escherichia coli, Salmonella enteritidis, Salmonella enterica a Salmonella typhimurium), a proto je široce používán $\mathrm{v}$ konzervaci potravin (Montanari 2014).

Významnou léčivou rostlinou je levandule zoubkatá, která sice nemá srovnatelně silné antioxidanty jako tymián nebo jiné rostliny z čeledi hluchavkovitých (Lamiaceae), ale disponuje antikarcinogenními, antialergickými, antiseptickými a analgetickými účinky. $Z$ květů levandule se připravuje nálev nebo odvar. Levandule je aplikována zejména na nachlazení, horečku, bolest hlavy nebo žaludku, premenstruační syndrom, bolestivou menstruaci, infekce ženských pohlavních orgánů nebo kožní infekce, poranění a obtíže. Z levandule se extrahuje esenciální olej, který je v tradiční medicíně použiván při obtížích trávicího traktu. Levandulový olej vykazuje antimikrobiální aktivitu, proto prospívá pleti 

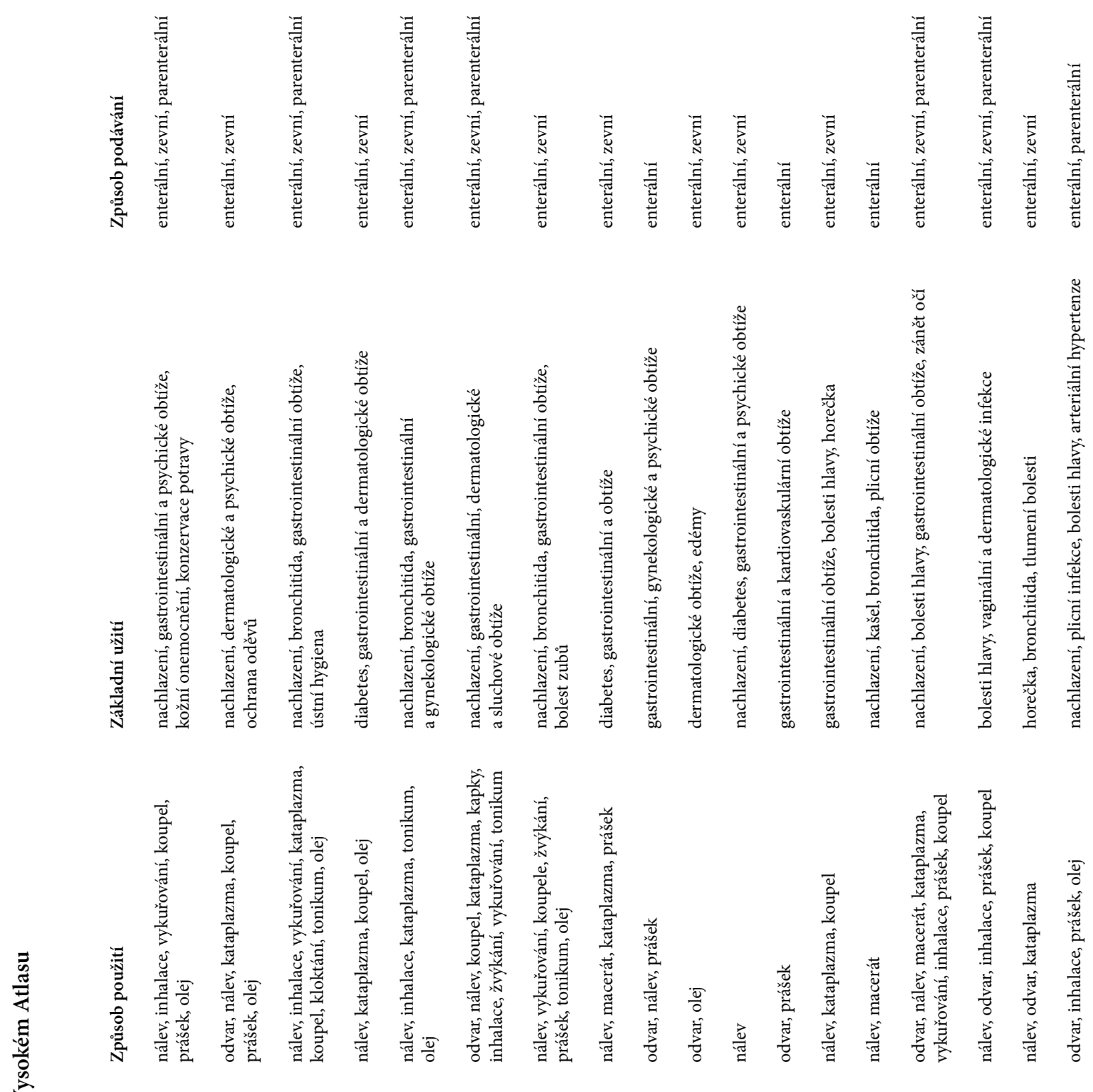

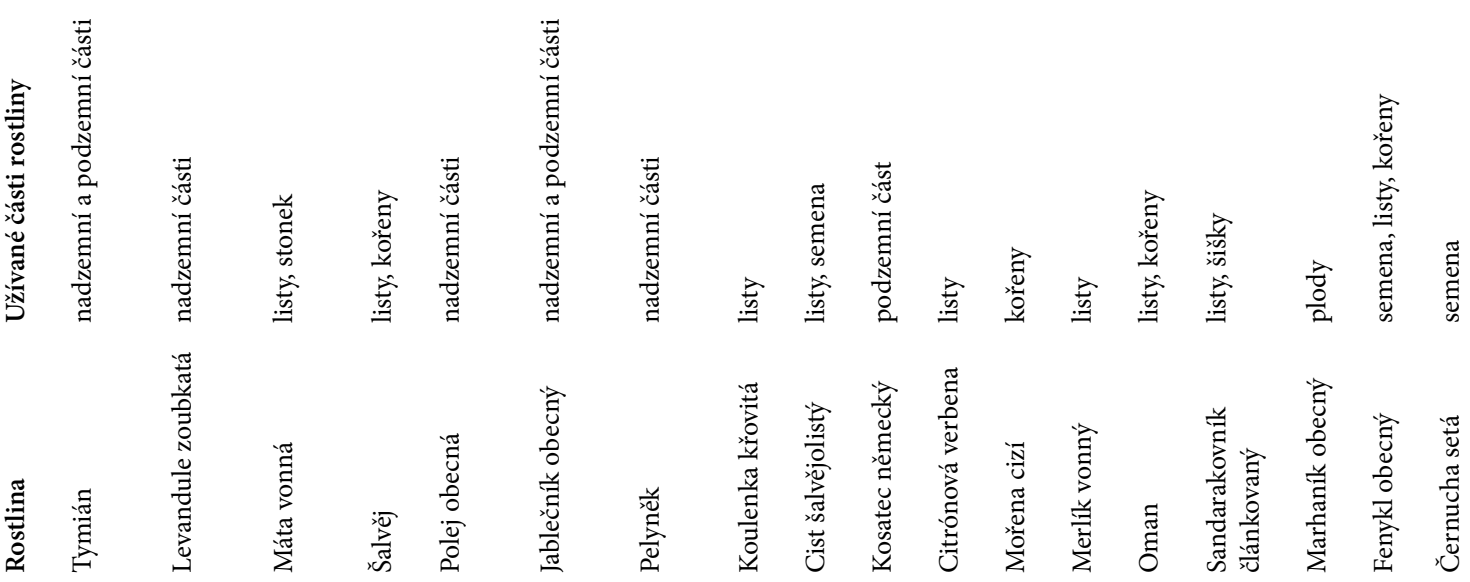




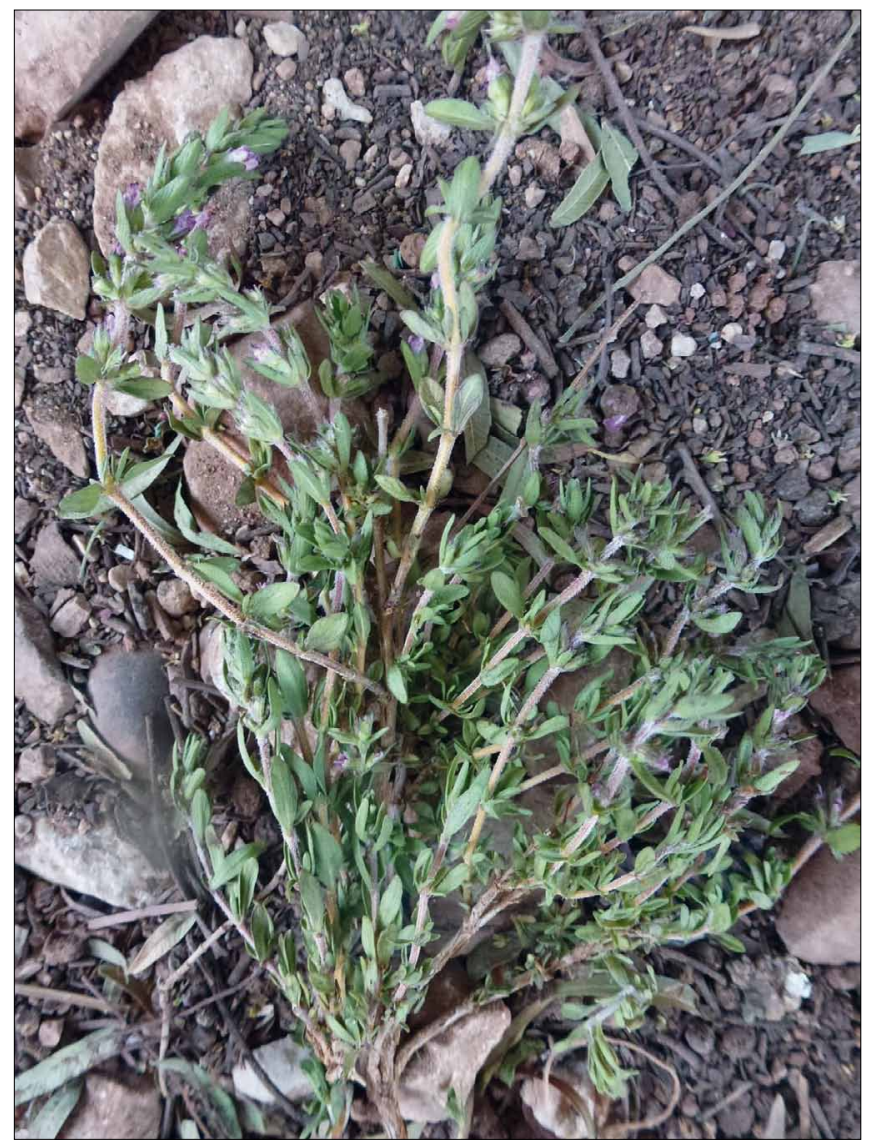

Tymián je v pohoří Vysokého Atlasu sbírán a užíván pravidelně jako nálev během období sklizně nebo v sušené formě mimo období sklizně.

a zabraňuje alergické reakci. Jako uklidňující prostředek léčí insomnii, pocity úzkosti a nervozity. Pro vonné látky se levandule přidává do henové směsi na tetování nebo barvení vlasů. Slouží jako potpourri a ochraňuje oděvy před bakteriemi a choroboplodnými zárodky. Levandule je v pohoří Vysokého Atlasu přidávána do pícniny (Castleman 2004; Ghrabi 2005; Montanari 2014).

Máta vonná se $\mathrm{v}$ pohoří Vysokého Atlasu obecně používá na horečku, bronchitidu a nachlazení. Máta slouží jako trávicí prostředek ve formě nálevu. $\mathrm{V}$ letních měsících představuje extrakt $z$ máty ve směsi se zeleným čajem osvěžující nápoj. Další využití máty je v dentální hygieně, nebot' osvěžuje a zpř́ijemňuje dech. Bolesti a záněty zubů a dásní léčí výplachy a kloktání v dutině ústní. Při bolestech hlavy se listy máty potírají spánky. Antiseptické vlastnosti máty způsobují, že listy přikládané na kủži po bodnutí hmyzem zmírňují svědění, pálení nebo natékání poraněného místa. V berberské etnomedicíně se máta užívá př̀i léčbě žaludečních a zažívacích poruch. Zmírňuje také syndrom dráždivého tračníku, který charakterizují bolesti břicha, nadýmání nebo poruchy trávení. Ve směsi s dalšími léčivými rostlinami léčí poruchy menstruačního cyklu (amenorea) a bolestivou menstruaci (dysmenorea). Máta má vysoké antifungální a antibakteriální vlastnosti, čímž se stává jednou $\mathrm{z}$ nejžádanějších ingrediencí aplikovaných do parfémů nebo užívaných k extrakci

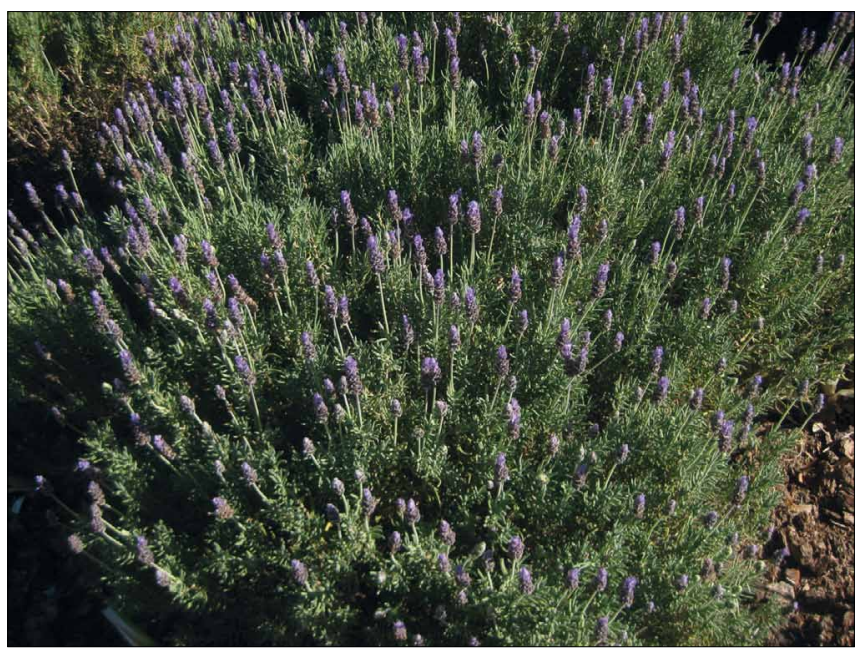

Levandule je užívána pro své léčivé účinky, ale pro vonné látky se přidává také do henové směsi na tetování nebo barvení vlasů.

esenciálního oleje (Castleman 2004; Derwich - Benziane Taouil 2010; Ainane - M'hammed Elkouali - Talbi 2014). Šalvěj je sbíraná na terasovitých polích nebo v horách Vysokého Atlasu. Ze šalvěje se obvykle získává nálev, někdy i ve směsi s dalšími léčivými rostlinami. Užívána je při léčbě žaludečních a střevních obtíží, bolesti žlučníku, zad, závratí, diabetes, poruch krevního oběhu nebo cerebrální ischemii. Tradičně je použivána při péči o pokožku a vlasy. Její antifungální účinky léčí různá kožní poranění a projevy revmatismu. Šalvěj zabraňuje rozvoji varikózních změn žilního systému a pročištuje krev. Příznivé účinky má na poruchy paměti, depresi a další neprríznivé duševní stavy. Pro své dezinfekční a antibakteriální účinky je úspěšně aplikovaná při léčbě plísní, otoků a při nadměrném pocení. Šalvěj představuje důležitý aromatický prostředek při vaření a je pro své osvěžující účinky běžně konzumována jako bylinný čaj. Z šalvěje se současně extrahuje esenciální olej (Bellakhdar 1997; El Abdouni Khiyari et al. 2014).

Polej obecná roste v blízkosti řek nebo na zavlažovaných terasovitých polích. Nadzemní části této rostliny obsahují širokou škálu sekundárních metabolitů, jako jsou třísloviny, pektiny nebo esenciální oleje. Čerstvé nebo sušené listy se běžně používají pro své léčebné a kulinářské vlastnosti. Polej charakterizují antispazmodické, antiseptické, antimikrobiální a protizánětlivé účinky. Užívána je zejména na nachlazení, kašel, zimnici, zažívací obtíže nebo na premenstruační syndrom a bolestivou menstruaci. Vedle toho je uživána jako abortivum $\mathrm{k}$ vypuzení nežádoucího plodu, zažívací prostředek a pletové tonikum (Derwich - Benziane - Taouil 2010). „Slouži také jako repelent proti blechám a jinému hmyzu. Je účinný při zmírnèní akné a dalších onemocnění kưže. "(Zekri et al. 2013, 608) Polej se užívá při inhalaci nebo jako kataplazma, nejčastěji na hrud' při plicní infekci. Z poleje je extrahován esenciální olej, který je využíván k léčbě chronické katarální bronchitidy, astmatické bronchitidy a černého kašle (Ghrabi 2005; Teixidor-Toneu et al. 2016).

Jablečník obecný působí proti bolesti hlavy, horečce, na žaludeční potíže nebo žaludeční a střevní obtíže. „Je to emenago- 


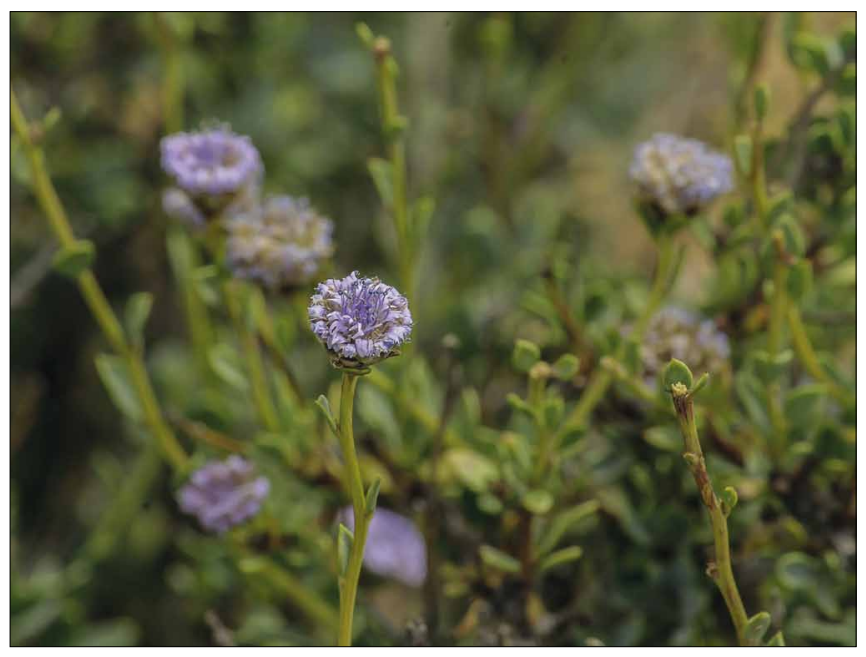

Koulenka křovitá - keř s modrými kulatými květy, který roste v pohoří Vysokého Atlasu, se použivá při léčbě diabetu nebo při renálních a kardiovaskulárních onemocněních.

gum, expectorans, antipyretikum, sedativum a stomachikum." (Montanari 2014, 35) K léčbě diabetu je jablečník užíván ve formě nálevu, kdy je využita celá rostlina bez semen. Při žaludeční bolesti se štáva $z$ listů smíchá s vodou a cukrem. Odvar z jablečníku pročištuje tělo, ale působí také jako stimulační tonikum na zesláblý organismus. Na bolest uší se v pohoří Vysokého Atlasu ze směsi štávy listů z jablečníku a olivového oleje vyrábí kapky, které se aplikují do zvukovodu. Další zevní použití jablečníku zahrnuje koupele, tonikum a kataplazma užívaná na kožní abscesy, boláky nebo špatně se hojící rány (Levey 1973; Boulos 1983; Castleman 2004; Montanari 2014). Z čeledi hvězdnicovitých je využíván zejména pelyněk, který nachází široké využití v berberské etnomedicíně. Pelyněk vykazuje „antidiabetické, kardiovaskulární, antimikrobiální, antioxidační, antiradikální, antispazmodické a neurologické účinky. "(Moufid - Eddouks 2012, 1155) Pelyněk je použiván jako diuretikum, střevní tonikum a antidiabetikum. Z nadzemní části rostliny se připravuje nálev. Pelyněk slouží pro orální i zevní použití, které zahrnuje koupele nebo vykuřování. Aplikuje se také jako prášek při léčbě obličejových skvrn. Zpravidla je ale využíván jako lék na nachlazení, bronchitidu, plicní, žaludeční, žlučníkové a střevní obtíže, bolesti hlavy a zubů, zejména pak po extrakci. Rostlina je však ve vysokých dávkách toxická, proto může vyvolat zvracení a křeče. Z pelyňku je extrahován esenciální olej. Extrakt z pelyňku ve směsi se zeleným čajem představuje zimní nápoj (Bellakhdar 1997; Abu-Rabia 2015; Teixidor-Toneu et al. 2016).

Z čeledi jitrocelovitých je $\mathrm{v}$ berberské medicíně široce vyhledávána koulenka křovitá - keř s modrými kulatými květy, který roste $\mathrm{v}$ horách. $\mathrm{Z}$ listů se připravuje nálev a macerát. „Její listy se tradičně používají jako hypoglykemická látka, projímadlo, cholagogum, stomachikum, projímadlo a prostředek na pocení. "(Es-Safi et al. 2006, 85) Koulenka se používá při léčbě diabetu nebo při renálních a kardiovaskulárních onemocněních. Dále je aplikována na bolesti hlavy, žaludeční a menstruační obtíže nebo zvracení. Často je smíchávána s ji-

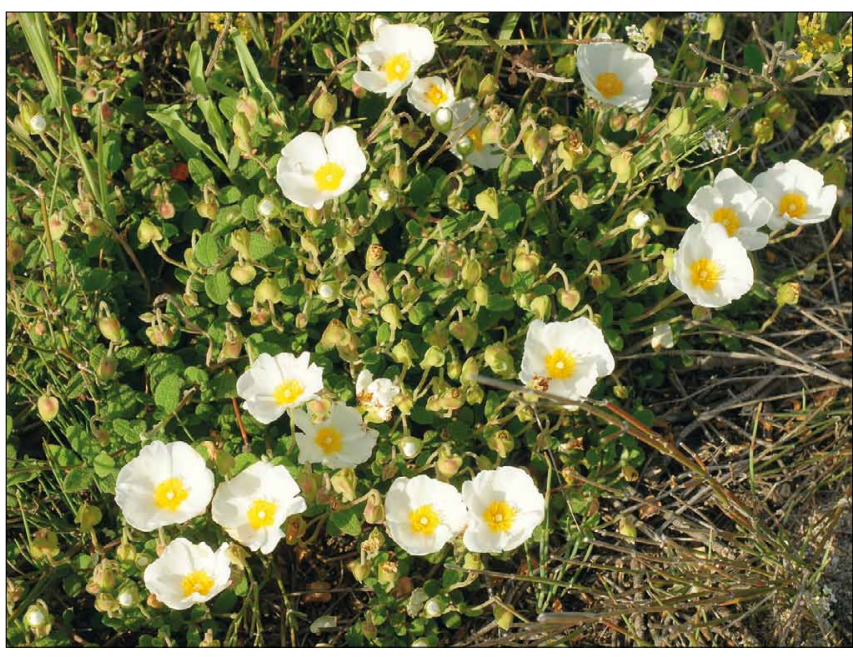

Listy a semena cistu šalvějolistého jsou tradičně užívané $\mathrm{v}$ berberské medicíně pro své protizánětlivé a antinociceptivní účinky.

nými rostlinami, protože má silnou chut. Musí být podávána s opatrností, protože vyvolává závratě, oligurii, průjem, hypotermii a pomalou pulzovou frekvenci (Bnouham et al. 2002; Khlifi et al. 2005).

$\mathrm{Z}$ čeledi cistovitých mezi rostliny užívané v berberské medicíně patří cist šalvějolistý, který má protizánětlivé a antinociceptivní účinky. Obecně je podáván na žaludeční a střevní potíže, poruchy trávení, bolestivou menstruaci, zimnici nebo revmatismus (Teixidor-Toneu et al. 2016). Cist je vyhledáván při léčbě nechutenství a nízké tělesné hmotnosti. Cist je zároveň považován za účinné afrodiziakum a antidepresivum. Obvykle se ze semen cistu připravuje nálev nebo odvar. Na bolesti žaludku jsou listy cistu smíchány s dubem cesmínovým (Quercus ilex). Cist je důležitá ingredience při přípravě tquawt, marockého pokrmu ze směsi mouky, medu, olivového oleje, mletých mandlí a vlašských ořechů. Tquawt se konzumuje $\mathrm{v}$ zimě nebo během oslav, jako jsou svatby a ramadán, kdy se tradičně podává jako předkrm s čajem (Montanari 2014).

$\mathrm{Z}$ čeledi kosatcovitých roste $\mathrm{v}$ terasovitých polích Vysokého Atlasu kosatec německý, jenž má antispazmodické, emenagogické, stimulující, diuretické a aperiodické účinky. Iridaly obsažené v oddencích vykazují cytotoxicitu vůči nádorovým onemocněním. Odvar z kořene (rhizon) uvolňuje otoky (edémy) a pomáhá při onemocnění žlučníku, zatímco štáva $\mathrm{z}$ oddenku je velmi účinná na čištění pleti a odstranění kožních skvrn, pih nebo boláků. Kosatec léčí pohlavní choroby a působí jako abortivum k vypuzení nežádoucího plodu. Z kořenů kosatce je také extrahován esenciální olej (Lavenderová 1999; Crisan - Cantor 2016).

Z čeledi sporýšovitých nachází v berberské medicíně uplatnění citrónová verbena. Jedná se o původně neendemickou rostlinu vyskytující se v pohoří Vysokého Atlasu, která se dnes pěstuje na terasovitých polích. V tradiční medicíně je vyhledávána pro své antispazmodické, antipyretické a sedativní vlastnosti. Úspěšně pomáhá také při léčbě nachlazení, diabetes, poruch trávení, nadýmání, kolice nebo při onemocnění 


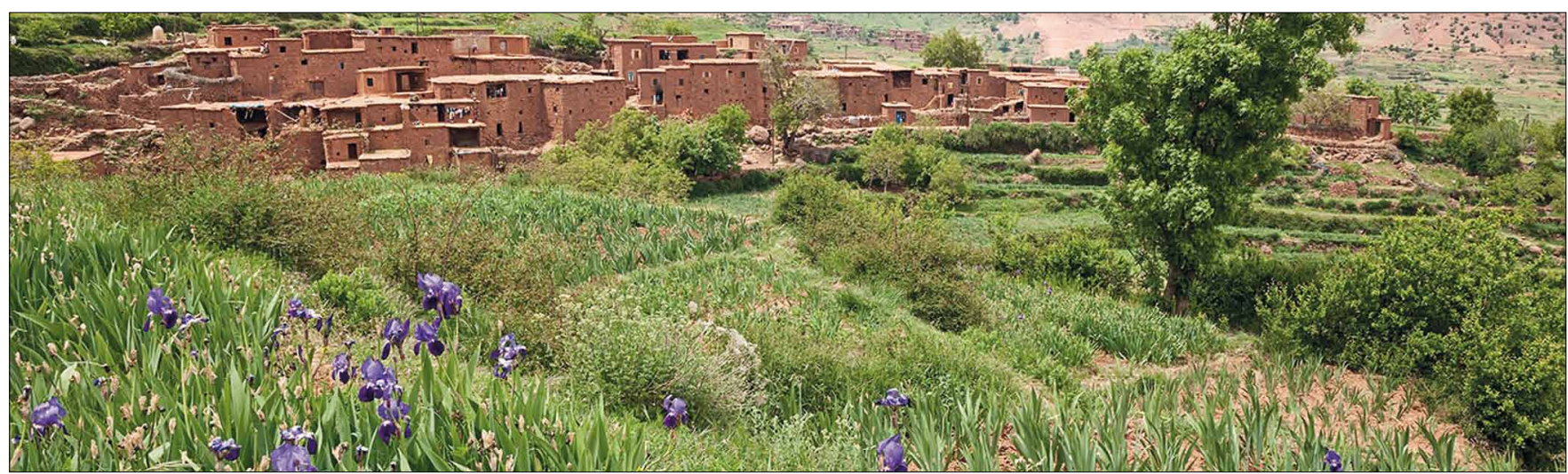

Na terasovitých polích Vysokého Atlasu roste kosatec německý, z jehož kořenů je extrahován esenciální olej.

krevního oběhu. Citrónová verbena má i uklidňující účinky, nebot odbourává bolesti hlavy, neschopnost koncentrace, nespavost a insomnii. Citrónová verbena se přidává do bylinných směsí, které uvolňují úzkosti a stres. Její listy jsou používány k nálevu a k extrakci esenciálního oleje, který vykazuje antimikrobiální aktivitu (Lavenderová 1999; Jamila - Mostafa 2014; Bensabah - Lamiri - Naja 2015).

$\mathrm{Z}$ čeledi mořenovitých kvete $\mathrm{v}$ kamenných stěnách $\mathrm{v}$ terasovitých polích mořena cizí, jejíž léčivé účinky má odvar. Mořena je účinná na kardiovaskulární, endokrinologické a gastrointestinální poruchy. Její kořeny mají antioxidační a antimikrobiální účinky, proto se aplikují na oběhové, srdeční a porodní problémy. Dále se používají jako diuretikum a emenagogum k ovlivnění menstruace (Teixidor-Toneu et al. 2016). V sušené formě je mořena doplňkem směsí užívaných při léčbě anemických obtíží, žloutenky a jaterních onemocnění. Z mořeny se extrahuje esenciální olej bohatý především na antrachinon, proto je oceňována při barvení kůží nebo vlny do různých odstínů červené. Pro své barvicí schopnosti se přidává i do tažínu, tradičního marockého dušeného pokrmu z masa a zeleniny (Paydar - Grammet 2002; Montanari 2014).

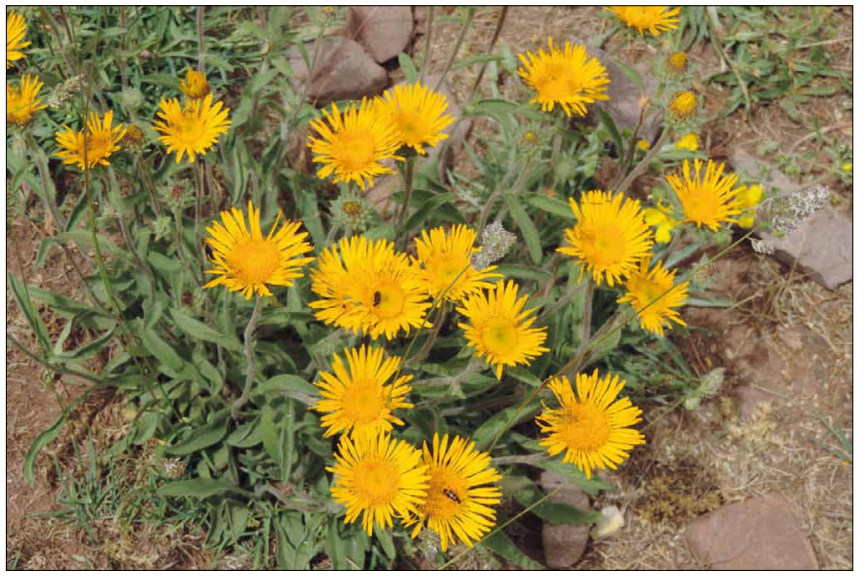

V horách a v okolí vesnic Vysokého Atlasu je sbírána vytrvalá bylina oman.
Z čeledi laskavcovitých je na březích řek Vysokého Atlasu oceňován pro své gastrointestinální, pediatrické a endokrinologické účinky merlík vonný. Funguje zejména jako účinné analgetikum, antipyretikum a antioxidant. Léčí také horečku, gastrointestinální onemocnění, astma a nadýmání. Listy merlíku smíchané s vodou nebo cibulí se v podobě obkladů kladou na hlavu při bolesti hlavy a horečce, zvláště $v$ případě dětských onemocnění. Usušené listy smíchané s vodou se užívají na migrénu a štáva extrahovaná $\mathrm{z}$ listů a spojená s pomerančovým džusem léčí horečku a bolest žaludku. V malých množstvích je merlík přidáván do bylinných směsích na léčbu horečky a bolesti hlavy (Montanari 2014; Ait Sidi Brahim et al. 2015).

$\mathrm{Z}$ čeledi hvězdnicovitých roste $\mathrm{v}$ horách a v okolí vesnic $\mathrm{Vy}$ sokého Atlasu vytrvalá bylina oman. Berberská etnomedicína oceňuje jeho gastrointestinální, otolaryngologické, respirační, rituální a duchovní vlastnosti. Oman se používá zejména na nachlazení, zimnici, bronchitidu, kašel nebo dráždění ke kašli. Z listů se připravuje nálev a macerát. Na nespavost je oman smícháván s horkým mlékem. Odvar z jeho kořenů je aplikován na bolesti očí. Kromě toho je prokázána jeho účinnost antihelmentika (Montanari 2014, Teixidor-Toneu et al. 2016).

Z čeledi cypřišovitých hraje $\mathrm{v}$ berberské medicíně významnou roli sandarakovník článkovaný. Jedná se o rostlinu, která vykazuje antioxidační, endokrinologické, gastrointestinální, otolaryngologické a respirační, urologické, nefrologické nebo rituální a duchovní účinky. Je využívána jako expektorans, diuretikum, emetikum a antidiabetikum. Slouží k léčbě nachlazení, horečky, bolesti hlavy a krku, úpalu nebo závratě. Sandarakovník je dále užíván na žaludeční obtíže, průjmy nebo záněty očí. Mezi způsoby použití patří vedle nálevu a odvaru také macerát nebo prášek, který se aplikuje prŕmo na rány nebo pupeční ránu novorozence (Bellakhdar 1997; Zidane Tits - Angenot et al. 2014).

Z čeledi kyprejovitých představuje silný antioxidant marhaník obecný, jenž má antiaterogenní, antihypertenzní a protizánětlivé vlastnosti. Plody tohoto menšího stromu jsou bohaté na flavonoidy, antokyaniny, kyselinu punicovou, ellagitaniny, alkaloidy, fruktózu, sacharózu, glukózu, jednoduché organické kyseliny a další složky. V berberské medicíně se plody mar- 


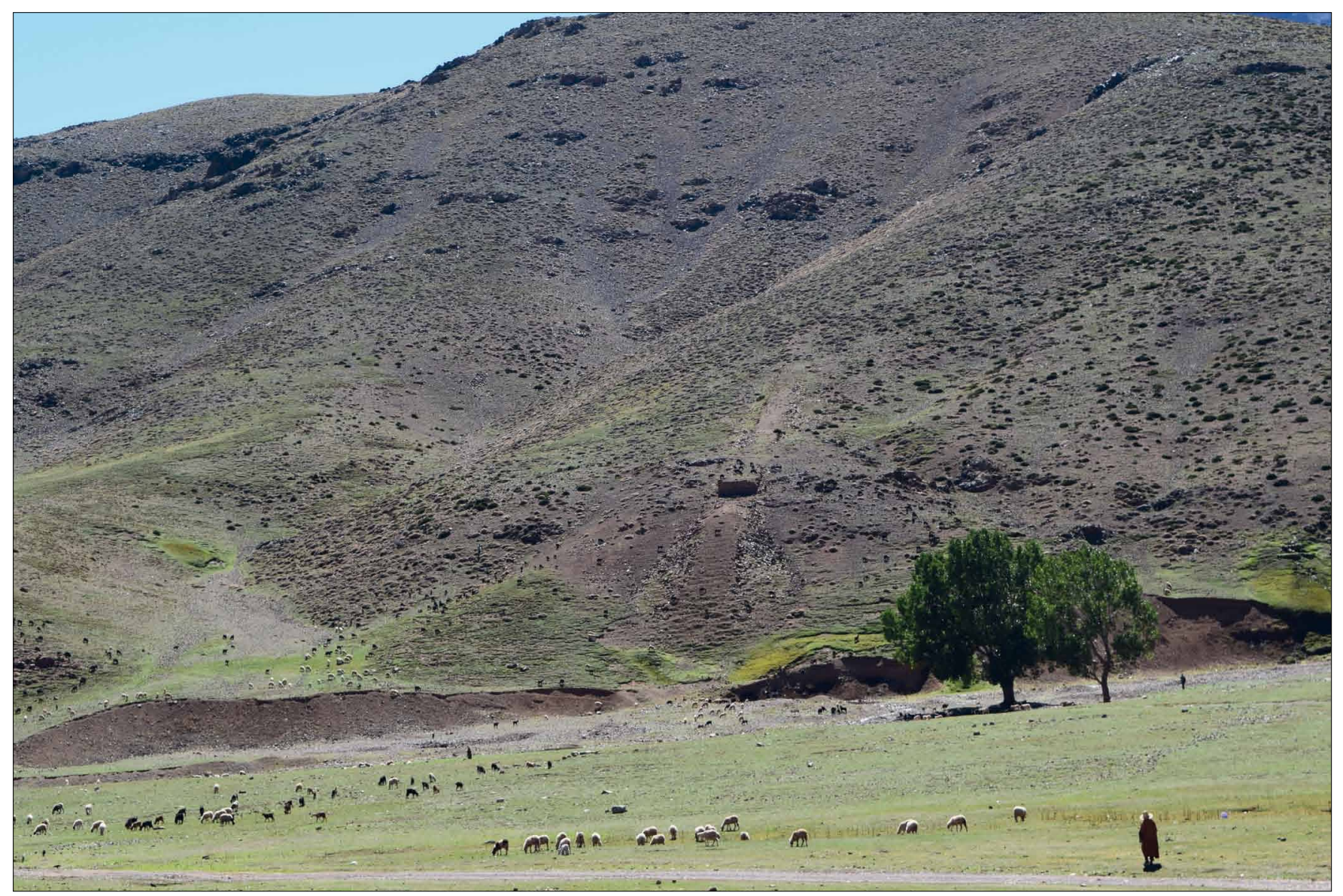

Berberští pastevci přesouvají zvířata v suchých letních měsících na pastviny ve vyšší nadmořské výšce, např́íklad do údolí Oukaïmeden ve Vysokém Atlasu, kde se nachází dostatek pastvy a voda.

haníku používají jako adstringens a diuretikum. Marhaník se doporučuje se při léčbě bolestí hlavy, průjmu, úplavice, žaludečního vředu, acidózy, krvácení a respiračních patologií. Působí i na kardiovaskulární onemocnění, osteoartritidu nebo revmatoidní artritidu. Užíván je i na vaginální a kožní infekce, opary nebo virové obrny. Jeho protizánětlivé vlastnosti a antibakteriální vlastnosti působí na záněty dásní a zlepšuje hojivost ran. Vyplachování úst extraktem z marhaníku odstraňuje i zubní plak (Bellakhdar 1997; Hmamouchi 1999; Chebaibi - Filali 2013).

Z čeledi miř́ikovitých berberská medicína využívá léčivé schopnosti fenyklu obecného. Tato bylina má gastrointestinální, oftalmologické, urologické, nefrologické a endokrinologické účinky. Léčí astma, bronchitidu, kašel, koliku nebo otravu jídlem. Fenykl tlumí bolest, horečku a usnadňuje odkašlávání. Také povzbuzuje chut' k jídlu, uklidňuje trávicí soustavu a urychluje hojení. Využíván je i na kožní a oční záněty nebo únavu očí. Vedle toho má mírný estrogenní účinek, jímž může vyvolávat menstruaci a tvorbu mléka kojících žen (Lavenderová 1999; Teixidor-Toneu et al. 2016).

Z čeledi pryskyřníkovitých je oceňována černucha setá, považovaná v berberské medicíně za bylinu, která „léčí všechny nemoci vyjímaje smrti." (Thurlkill 2016, 62) Rostlina obsahuje antioxidační, antidiabetické, analgetické, antimikrobiální, protizánětlivé, spasmolytické, antihypertenzní a renální látky. Je to rostlinné antibiotikum, které pomáhá regulovat hladinu cukru v krvi a normalizovat hladinu krevních lipidů. Pro léčebné účinky se zpracovávají semena $\mathrm{z}$ makoviček. Semena stimulují imunitní systém, nebot zvyšují počet bílých krvinek $\mathrm{v}$ průběhu infekce proti nežádoucím patogenům. Černucha je „inhalována jako rozdrcený prášek nebo používána jako diuretikum v boji proti chřipce, migrénè, sinusitide, plicním problémưm nebo astmatu." (Mateo Dieste 2013, 194) Semena černuchy se inhalují nejenom za účelem uvolnění dutin a bolesti hlavy, nýbrž i kvůli zmírnění chrápání. Semena jsou používána k extrahování oleje. Několik kapek v kávě nebo čaji léčí plicní infekci, kašel a nachlazení. Prášek ze semen se smíchává s medem na arteriální hypertenzi nebo jaterní onemocnění (Teixidor-Toneu et al. 2016).

\section{TRADIČNÍ MODEL UDRŽITELNÉHO VYUŽITÍ PŘÍRODNÍCH ZDROJŮ VE VYSOKÉM ATLASU}

Tradiční marocká společnost historicky vyvinula modely trvale udržitelného využívání životního prostředí a přírodních zdrojů. V pohoří Vysokého Atlasu ochranu rostlin zajištuje systém agdal (pl. igudlan, igdalen), který dočasně omezuje 


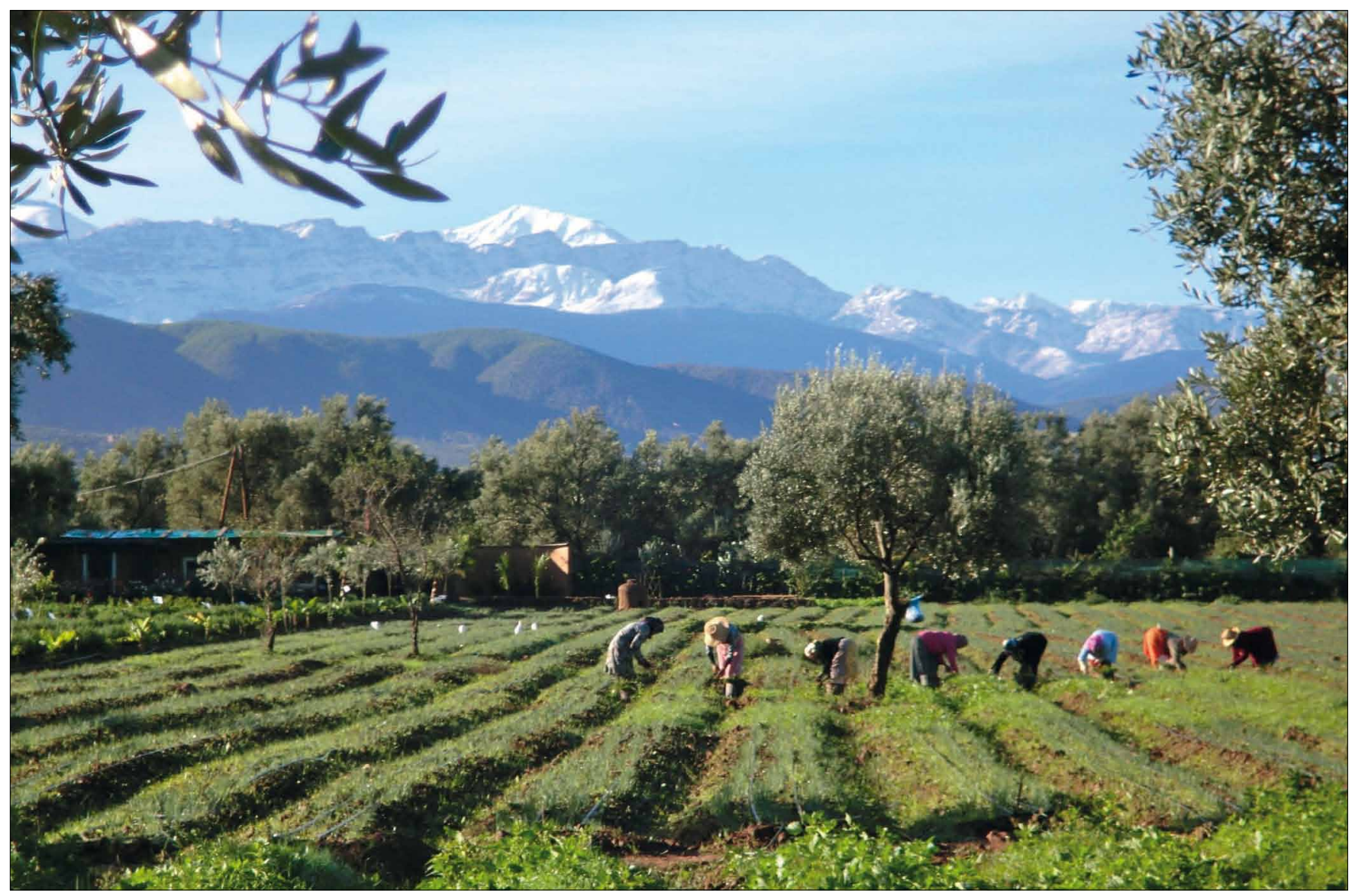

Léčivé a kosmetické účinky rostlin jsou návštěvníkům prezentovány v zahradách Le Paradis du Safran v údolí Ourika ve Vysokém Atlasu.

konkrétní využívání přírodních zdrojů. Jedná se o sezónní pastevectví a přesun dobytka mezi nížinami a horskými oblastmi (Genin - Simenel 2011; Půtová 2016). Agdal je kolektivní pastvina. Práva na prístup k ní a její využívání jsou řízena berberskými kmeny. Berberští pastevci sledují vzorce sezónní migrace, $\mathrm{v}$ zimě se stáda pasou v nízké nadmořské výšce. Poté dochází k sezónnímu přesunu zviřat na pastviny ve vyšší nadmořské výšce, kde se v suchých letních měsících nachází dostatek pastvy a voda (Auclair 1996; Genin - Simenel 2011). Pastevci nerozdělují stáda na základě živočišných druhů (ovce nebo kozy), ale upravují svou mikromobilitu na lokálních pastvinách, aby dokázali zohlednit různé potřeby krmení obou druhů přežvýkavců. Stáda s vyšším zastoupením koz mají snadný př́stup k horninám a spásají více fanerofytů, jako jsou xerofyty a polokeře. ${ }^{1}$ Stáda s vyšším zastoupením ovcí nejsou schopna využívat pastvu tímto způsobem. V důsledku musí

1 Marocké aromatické a léčivé rostliny v závislosti na svých životních formách tvoří přibližně $40 \%$ terofytů a hemikryptofytů (jednoletá rostlina bez obnovovacích pupenů a vytrvalá až dvouletá bylina s obnovovacími pupeny těsně nad povrchem půdy), $25 \%$ fanerofytů (dřevina s obnovovacími pupeny nad povrchem půdy), $20 \%$ chamaefytů (rostlina nebo nízká dřevina s obnovovacími pupeny nad povrchem půdy) a $15 \%$ geofytů (vytrvalá bylina s obnovovacími pupeny pod povrchem půdy), (Fennane, Rejdali 2016). pastevci být mobilnější, aby vyhověli potřebám krmení ovcí. Období a způsoby využívání přírodních zdrojů se může lišit v závislosti na srážkách, dynamice stád nebo na sociokulturních faktorech.

Kořeny agdal se odvíjí od historie severoafrických pasteveckých společností, které měly vždy potřebu chránit a odkládat používání některých pastvin, aby bylo možné disponovat krmivem v kritických obdobích (Gellner 1969; Ilahiane 1999; Mahdi 1999; Venema - Mguild 2002). Ve Vysokém Atlasu však odkazuje také na různorodé zdroje a ekosystémy. Agdal lze aplikovat na lesy, pastviny, ovoce, zemědělské produkty, krmivo nebo léčivé rostliny. Agdal zahrnuje geografický a agroekologický prostor, který charakterizuje fyzické prostředí a specifické biotické zdroje (rostliny, pastviny a zemědělství). Vztahuje se zejména na ochranu rostlin na letních pastvinách během vegetační doby. Agdal umožňuje zachování a regeneraci a minimalizuje degradaci zdrojů prostřednictvím transhumance.

Systém agdal představuje výsledek interakcí mezi člověkem a př́rodou, jejichž prostřednictvím berberské společnosti rozvinuly znalosti a praktiky za účelem adaptace na omezující a proměnlivé prostředí. Dokládá hluboké domorodé znalosti, ekologické poznatky a pochopení složitosti př́rodních zdrojů (Berkes 1999). Systém agdal umožňuje Berberům kontrolovat své území a dlouhodobě uvažovat o zachování a využívání ko- 


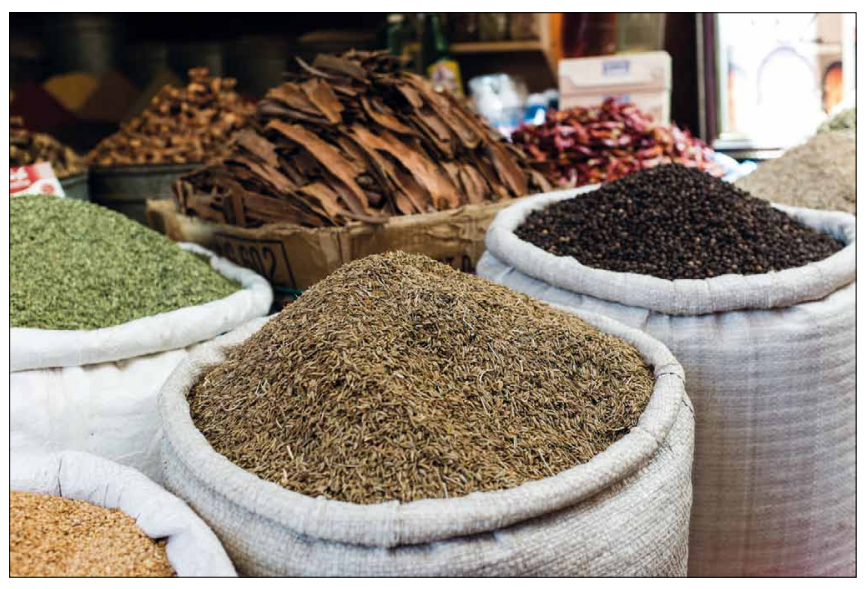

Sušené léčivé rostliny, jako např́iklad koriandr setý, jsou k prodeji na tržišti (súk) v Marrákeši.

lektivních zdrojů. Tento způsob řízení podporuje solidaritu, posiluje komunitní autonomii a integritu. Agdal má zásadní význam v udržování berberské identity, protože je umístěn v kolektivní paměti, vnímání lokální historie a původu komunity (Mahdi 1999; Dominguez et al. 2010). V současnosti se systém agdal proměňuje s ohledem na vztah k zemědělství, trhu, rozvoji turistického ruchu a sezónní mobilitě populace nebo nakonec její emigraci (Genin - Simenel 2011; Akasbi et al. 2012). Proměna systému agdal má dopad na lidi a jejich užívání rostlin za účelem nejenom obživy, ale především pak léčby. Tato změna se podílí na neudržitelném využívání př́rodních zdrojů ve Vysokém Atlasu, které ovlivňují podnikatelské aktivity, zásahy státu, proměny zpo̊sobu života lokálního obyvatelstva i vztahy turistů a hostitelů.

\section{NEUDRŽITELNÉ VYUŽITÍ PŘíRODNÍCH ZDROJŮ VE VYSOKÉM ATLASU}

Obchodování s léčivými a aromatickými rostlinami v pohoří Vysokého Atlasu má pro Berbery prŕnos v socioekonomické oblasti. Vlivem rostoucí poptávky po rostlinách, fytoterapii, esenciálních olejích a rostlinném materiálu jsou však přírodní zdroje neudržitelně využívány a překračují prahovou hodnotu regenerace (Sheldon - Balick - Laird 1997). Narůstající intenzita využívání rostlinných zdrojů $\mathrm{v}$ pohoří Vysokého Atlasu vede ke snížení vegetace, ztrátě biodiverzity a postupnému nárůstu desertifikace (Gauquelin et al. 1999; Hmamouchi 1999). Negativní dopady na životního prostředí se dále propojují s odlesněním v horských oblastech, včetně ztráty keřové vegetace, nadměrného spásání rostlin a eroze půdy. Svůj podíl na ničení místních ekosystémů mají také cestovní ruch a další rekreační aktivity, které ovlivňují fungování systému agdal a jeho principů využívání rostlinných zdrojů. K destrukci životního prostředí přispívá také rozvoj tržní ekonomiky, globalizace a rostoucí poptávka ze strany celostátních a mezinárodních trhů (Benabid 1996; Margaris 1996; Maselli 1996). V Maroku představuje obchodování s aromatickými a léčivými rostlinami velmi výnosné podnikání, které zahr-

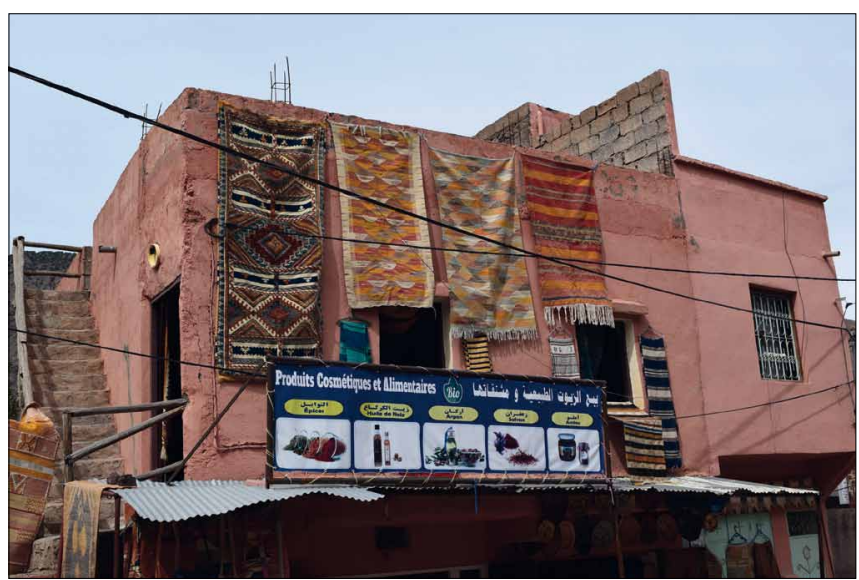

Léčivé i kosmetické produkty je možné zakoupit ve vesnicích v údolí Ourika ve Vysokém Atlasu.

nuje produkci esenciálních olejů, rostlinných extraktů a dalších rostlinných esencí. Obchodování probíhá v turistických zónách ve vesnicích Vysokého Atlasu, na marockých tržištích (súky), především v Marrákeši nebo v Casablance, výrazně je však zaměřeno na export do zemí Evropy. Hlavními rostlinami, které se stávají součástí komerčního využití jsou tymián (Thymus), levandule (Lavandula), šalvěj (Salvia aucheri), rozmarýn lékařský (Rosemary officinalis), pelyněk (Artemisia herbaalba Asso) nebo polej obecná (Mentha pulegium L.), (Kouhila et al. 2002; Montanari 2014).

Zejména oleje $\mathrm{z}$ tymiánu a levandule jsou široce používány ve farmacii, kosmetice, aromaterapii a v potravinářském průmyslu. Současné praktiky využívání jsou nebezpečné pro přirozenou ekologickou rovnováhu, protože nezohledňují limity místního ekosystému a vyžadují vyšší produkci, než přináší přiměřená a správně provedená sklizeň. Sklizeň rostlin se provádí vykořeněním rostlin, čímž některé končí svůj vegetační život. Jiným klesá odolnost proti škůdcům a chorobám. Naprríklad nekontrolovaný sběr tymiánu a šalvěje představují ekologický problém, nebot rostliny jsou vytrhávány i s kořeny. Problémem se stává, že „rostliny jsou velmi staré a jejich regenerace ze semena je ohrožena, protože na poli žádné nezůstávají a nemohou tak vzklícit semena, která by zajistila obnovu osiva." (Zenasni - Bakhy - Gaboun et al. 2004, 509) Oproti tomu levandule není natolik ohrožená, nebot’ sklizeň spočívá pouze v řezání květů nebo kvetoucích natí. Ačkoliv jsou potenciál a účinky aromatických a léčivých rostlin rozšířeny v berberské společnosti, schází odborná znalost o přesné morfologii, taxonomii a chorologii využívaných druhů. Postupně tak narůstá počet ohrožených druhů bylin, z nichž některé jsou endemické rostliny (Cunningham 2001; El-Hilaly - Hmammouchi - Lyoussi 2003).

Obchodování s rostlinami je podpořeno i rozvojem cestovního ruchu ve Vysokém Atlasu, do něhož jsou zapojeni Evropané, především Francouzi a Britové, nebo bohatí Maročané $\mathrm{Z}$ větších měst. Bohatství pohoří a jeho údolí začaly být uznávány jako součást kulturního a přírodního dědictví. Lokální zdroje se transformují na objekty turistického ruchu také za účelem podpory lokální identity a historie. Vedle prožitku 


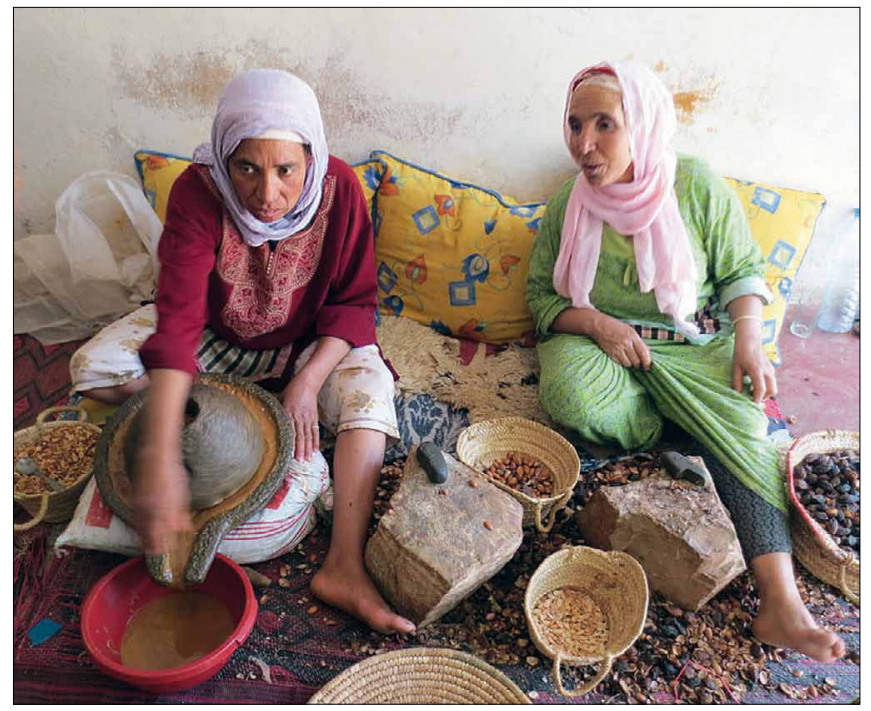

Berberské ženy roztloukají jádra arganových ořechů v údolí Ourika ve Vysokém Atlasu. V kamenných mlýnech je drtí na kaši (amlou), do níž se přidává voda, jež se přefiltruje, aby vznikl čistý přírodní olej.

z přírodního prostředí je vyhledávané zapojení do tradičního způsobu života berberské společnosti (Chevallier 2000). Někteří lokální aktéři v oblasti cestovního ruchu, zejména horští průvodci, majitelé stravovacích podniků a ubytoven, dokážou využít teritoriálních zdrojů prostřednictvím tradičních dovedností a znalostí. Cestovní ruch přináší nároky na zlepšení základní infrastruktury a služeb, jako je budování širokých silnic $\mathrm{v}$ masivu hor, dostupnost elektřriny, ubytovací a stravovací zařízení nebo obchody. Tato restrukturalizace území má ovšem negativní dopad na tradiční berberskou společnost a př́rodní prostředí. Postupně se opouští závlahové zemědělství a transhumantní migrace včetně systému agdal. $\mathrm{V}$ posledních třech desetiletích tyto aktivity potlačila dočasná námezdní práce $\mathrm{v}$ turistickém ruchu, $\mathrm{v}$ městských aglomeracích nebo trvalé usazení ve městě (Crawford 2008; Breuer et al. 2011). Př́mý dopad turistického ruchu, jako je pěší turistika nebo cykloturistika, na přírodní prostředí vede k intenzivnímu a opakovanému využívání cest, půdy a vegetace. Konkrétně pak zahrnuje pokles regenerace vegetace, ztrátu půdní organické hmoty, vysokou poréznost a znečištění půdy nebo zanesení a znečištění odpadky (Sunlu 2003). V důsledku toho může postupně docházet $\mathrm{k}$ zániku některých druhů bylin a rostlin, užívaných v berberské etnomedicíně, které následně povede ke ztrátě pluralitního medicínského přístupu v Maroku.

\section{ZÁVĚR}

Berberská etnomedicína $\mathrm{v}$ pohoří Vysokého Atlasu, která zahrnuje systém tradičních léčebných znalostí a dovedností, dodnes představuje autonomní a svébytný způsob léčby psychické i fyzické dimenze lidského těla. Je tomu tak, přestože biomedicína ovlivnila nativní klasifikaci nemocí, způsob dia-

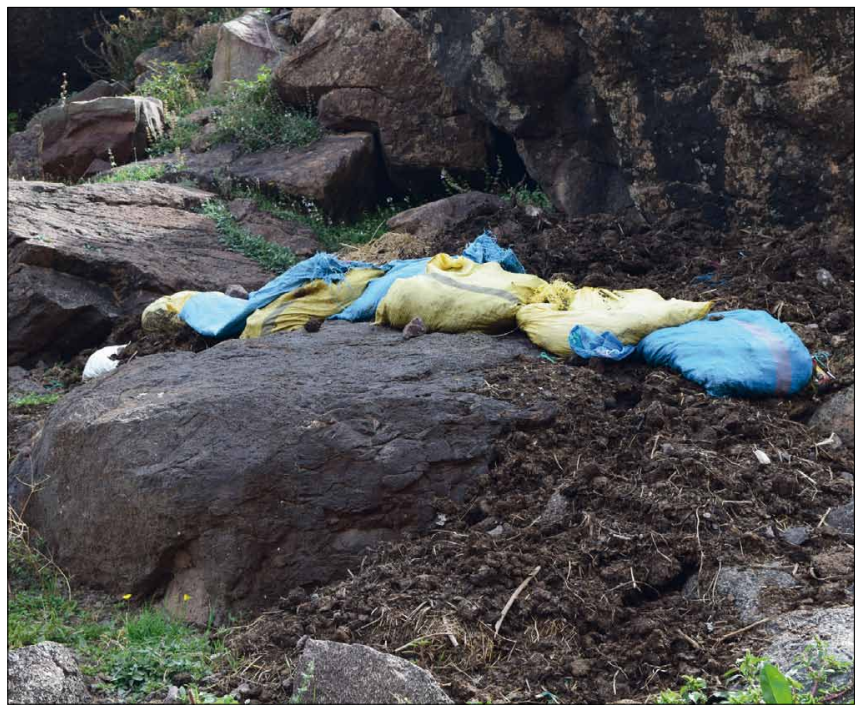

Odpadky znečištují vesnice a svahy Vysokého Atlasu, čímž může postupně docházet $\mathrm{k}$ zániku některých druhů bylin a rostlin, užívaných $\mathrm{v}$ berberské etnomedicíně.

gnostiky, léčebné postupy nebo užitá léčiva. Vedle biomedicíny, jež na území Maroka pronikla již za francouzské koloniální nadvlády, berberskou etnomedicínu v současné době proměňuje a potlačuje vzestup ortodoxní formy islámu a státem podporovaná modernizace prosazující se v oblasti zdravotnictví a školství. Negativní vliv na ekosystém Vysokého Atlasu a berberskou etnomedicínu má také rostoucí poptávka po léčivých rostlinách, fytoterapii a esenciálních olejích. Berberskou etnomedicínu je nezbytné vnímat, chránit a uchovat nejenom jako doklad alternativního přístupu k péči o lidské zdraví, nýbrž také jako zdroj medicínských poznatků a léčebných postupů, jež se v různé formě mohou stát inspirací pro biomedicínu.

\section{LITERATURA}

Abouri, Mustapha - El-Mousadik, Abdelhamid - Msanda, Fouad et al. (2012): An Ethnobotanical Survey of Medicinal Plants Used in the Tata Province, Morocco. International Journal of Medicinal Plant Research, 1, 99-123.

Abu-Rabia, Aref (2015): Indigenous Medicine Among the Bedouin in the Middle East. New York: Berghahn.

Ainane, Tarik - Elkouali, M'hammed - Ainane, Ayoub - Talbi, Mohammed (2014): Moroccan Traditional Fragrance Based Essential Oils: Preparation, Composition and Chemical Identification. Der Pharma Chemica, 6(6), 84-89.

Ait Sidi Brahim, Malika - Fadli, Mariam - Hassani, Lahcen et al. (2015): Chenopodium ambrosioides var. ambrosioides Used in Moroccan Traditional Medicine Can Enhance the Antimicrobial Activity of Conventional Antibiotics. Industrial Crops and Products, 71, 37-43.

Akasbi, Zakia - Oldeland, Jens - Dengler, Jürgen - Finckh, Manfred (2012): Social and Ecological Constraints on Decision Making by Transhumant Pastoralists: A Case Study From the Moroccan Atlas Mountains. Journal of Mountain Science, 9, 307-321.

Altorki, Soraya (2015): A Companion to the Anthropology of the Middle East. Chichester: Wiley Blackwell.

Auclair, Laurent (1996): L'appropriation communautaire des forets dans le Haut Atlas marocain. Cahier des Sciences Humaines, 32, 177-194. 
Auclair, Laurent - Alifriqui, Mohamed eds. (2013): Agdal: Patrimoine socio-écologique de l'Atlas marocain. Rabat: IRCAM-IRD.

Baer, Hans A. (2004): "Medical Pluralism." In: Encyclopedia of Medical Anthropology: Health and Illness in the World's Cultures, edited by Carol R. Ember and Melvin Ember, 109-116. Dordrecht: Kluwer Academic/Plenum Publishers.

Baer, Hans A. - Singer, Merrill - Susser, Ida (1997): Medical Anthropology and the World System: Critical Perspectives. Westport: Bergin \& Garvey.

Bakker, Jogien (1992): The Rise of Female Healers in the Middle Atlas, Morocco. Social Science \& Medicine, 35, 819-829.

Bannerman, Robert H. - Burton, John - Wen-Chieh, Ch'en eds. (1983): Traditional Medicine and Health Care Coverage. Geneva: World Health Organisation.

Bellakhdar, Jamal (1989): A New Look at Traditional Medicine in Morocco. World Health Forum, 10, 193-199.

Bellakhdar, Jamal (1997): La pharmacopée marocaine traditionnelle: Médecine arabe ancienne et savoirs populaires. Paris: Ibis Press.

Benabid, Abdelmalek (1996): "Forest Degradation in Morocco." In: The North African Environment at Risk, edited by Will Davis Swearingen and Abdellatif Bencherifa, 175-189. Boulder: Westview.

Benabid, Abdelmalek (2000): Flore et écosystèmes du Maroc: Évaluation et préservation de la biodiversité. Paris: Ibis Press.

Bensabah, Fatima - Lamiri, Abdeslam - Naja, Jamal (2015): Effect of Purified Wastewater From the Fity of Settat (Morocco) on the Quality of Lippia citriodora Essential Oil and Infusion. Journal of the Saudi Society of Agricultural Sciences, 14(2), 101-108.

Berkes, Fikret (1999): Sacred Ecology: Traditional Ecological Knowledge and Resource Management. Philadelphia: Taylor and Francis.

Bnouham, Mohamed - Mekhfi, Hassane - Legssyer, Abdelkhaleq et al. (2012): Medicinal Plants Used in the Treatment of Diabetes in Morocco. International Journal of Diabetes \& Metabolism, 10, 33-50.

Boulos, Loutfy (1983): Medicinal Plants of North Africa. Algonac: Reference Publications.

Breuer, Ingo - Gertel, Jörg - Kreuer, David et al. (2011): "Landwirtschaftliche Existenzsicherung am Limit?” In: Alltagsmobilitäten: Aufbruch marokkanischer Lebenswelten, edited by Jörg Gertel and Ingo Breuer, 83-112. Bielefeld: Transcript Verlag.

Castleman, Michael (2004): Velká kniha léćivých rostlin. Klasický prưvodce nejlepšími prrírodnimi léćivy prèedstavující ty nejlepši - časem i vědou prověrené - léčivé rostliny. Praha: Columbus.

Crandon, Libbet (1986): Medical Dialogue and the Political Economy of Medical Pluralism: A Case From Rural Highland Bolivia. American Ethnologist, 13(3), 463-476.

Crawford, David (2008): Moroccan Households in the World Economy. Louisiana: Louisiana State University Press.

Crisan, Ioana - Cantor, Maria (2016): New Perspectives on Medicinal Properties and Uses of Iris sp. Hop and Medicinal Plants, 24(1-2), 24-36.

Cunningham, Anthony B. ed. (2001): Applied Ethnobotany: People, Wild Plant Use and Conservation. London: Earthscan.

Derwich, Elhoussine - Benziane, Zineb - Taouil, Rachid (2010): GC/MS Analysis of Volatile Compounds of the Essential Oil of the. Leaves of Mentha pulegium Growing in Morocco. Chemical Bulletin of "Politehnica", 55(69), 103-106.

Dominguez, Pablo - Bourbouze, Alain - Demay, Sébastien et al. (2013): Diverse Ecological, Economic and Socio-Cultural Values of a Traditional Common Natural Resource Management System in the Moroccan High Atlas: The Ait Ikiss Tagdalts. Environmental Values, 21(3), 277-296.

Dow, James W. (1986): Universal Aspects of Symbolic Healing: A Theoretical Synthesis. American Anthropologist. New Series, 88(1), 56-69.

El Abdouni Khiyari, Mohamed - Kasrati, Ayoub - Alaoui Jamali, Chaima et al. (2014): Chemical Composition, Antioxidant and Insecticidal Properties of Essential Oils From Wild and Cultivated Salvia aucheri subsp. blancoana (Webb. \& Helder), an Endemic, Threatened Medicinal Plant in Morocco. Industrial Crops and Products, 57, 106-109.

El-Hilaly, Jaouad - Hmammouchi, Mohamed - Lyoussi, Badiâa (2003): Ethnobotanical Studies and Economic Evaluation of Medicinal Plants in Taounate Province (Northern Morocco). Journal of Ethnopharmacology, $86,149-158$

Es-Safi, Nour-Eddine - Khlifi, Samira - Kollmann, Albert et al. (2006): Iridoid Glucosides From the Aerial Parts of Globularia alypum $L$.
(Globulariaceae). Chemical and Pharmaceutical Bulletin, 54(1), 85-88. Feierman, Steven - Janzen, John M. eds. (1992): The Social Basis of Health \& Healing in Africa. Berkely: University of California.

Fennane, Mohamed - Rejdali, Moh (2016): Aromatic and Medicinal Plants of Morocco: Richness, Diversity and Threats. Bulletin de l'Institut Scientifique, Section Sciences de la Vie 38: http://www.israbat.ac.ma/wp-content/uploads/2017/01/Manuscrit_BIS.SV.18-16_Fennane_MEP_(12.1.2017).pdf

Gaines, Atwood D. - Davis-Floyd, Robbie (2004): „Biomedicine.“ In: Encyclopedia of Medical Anthropology: Health and Illness in the World's Cultures, edited by Carol R. Ember and Melvin Ember, 95-109. Dordrecht: Kluwer Academic/Plenum Publishers.

Gauquelin, Thierry - Bertaudiere-Montes, Valerie - Montes, Nicolas et al. (1999): Endangered Stands of thuriferous juniper in the Western Mediterranean Basin: Ecological Status, Conservation and Management. Biodiversity and Conservation, 8, 1479-1498.

Ghanmi, Mohamed - Satrani, Badr - Aberchane, Mohamed et al. (2011): Plantes Aromatiques et Médicinales du Maroc: les milles et une vertu. Rabat: Centre de Recherche Forestière.

Ghrabi, Zeineb (2005): A Guide to Medicinal Plants in North Africa. Málaga: IUCN Centre for Mediterranean Cooperation.

Génin, Didier - Simenel, Romain (2011): Endogenous Berber Forest Management and the Functional Shaping of Rural Forests in Southern Morocco: Implications for Shared Forest Management Options. Human Ecology, 39(3), 257-269.

Greenwood, Bernard (1981): Cold or Spirits? Choice and Ambiguity in Morocco's Pluralistic Medical System. Social Science \& Medicine. Part B: Medical Anthropology, 15, 219-235.

Helman, Cecil G. (2008): Medical Anthropology. London: Routledge.

Hseini, Souâda - Kahouadji, Azzeddine (2007): Étude ethnobotanique de la flore médicinale dans la région de Rabat (Maroc occidental). Lazaroa, 28, 79-92.

Hmamouchi, Mohammed (1999): Les plantes médicinales et aromatiques marocaines. Mohammedia: Imprimerie Fédala.

Chebaibi, Amina - Rhazi Filali, Fouzia (2013): Bactericidal Activity and Phytochemical Screening of Moroccan pomegranate (Punica granatum Linn.) Peel Aqueous Extracts. Journal of Medicinal Plants Research, 7(14), $887-891$.

Chevallier, Denis (2000): Vives campagnes: le patrimoine rural, projet de société. Paris: Éditions Autrement.

Ilahiane, Hsain (1999): The Berber Agdal Institution: Indigenous Range Management in the Atlas Mountain. Ethnology, 38(1), 21-45

Jamila, Fakchich - Mostafa, Elachouri (2014): Ethnobotanical Survey of Medicinal Plants Used by People in Oriental Morocco to Manage Various Ailments. Journal of Ethnopharmacology, 154, 76-87.

Janzen, John M. - Prins, Gwyn (1981): Causality and Classification in African Medicine and Health. Social Science and Medicine, 158(3), 169-172.

Jirásek, Václav - Starý, František (1986): Atlas léčivých rostlin. Praha: Státní pedagogické nakladatelství.

Jones, R. Kenneth (2004): Schism and Heresy in the Development of Orthodox Medicine: The Threat to Medical Hegemony. Social Science and Medicine, 58(4), 703-712.

Kapchan, Deborah A. (1996): Gender on the Market: Moroccan Women and the Revoicing of Tradition. Philadelphia: University of Pennsylvania Press.

Khlifi, Samira - El Hachimi, Youssef - Khalil, Abdelouahed et al. (2005): In vitro Antioxidant Effect of Globularia alypum L. Hydromethanolic Extract. Indian Journal of Pharmacology, 37, 227-231.

Kim, Jim Yong (2000): Dying for Growth: Global Inequality and the Health of the Poor. Monroe: Common Courage Press.

Kleinman, Arthur (1978): Concepts and a Model for the Comparison of Medical Systems As Cultural Systems. Social Science \& Medicine. Part B: Medical Anthropology, 12, 85-93.

Kleinman, Arthur (1988): The Illness Narratives: Suffering, Healing, and the Human Condition. New York: Basic Books.

Kouhila, Mohammed - Fliyou, Mohammed - Otmani, Mohammed et al. (2002): Experimental Study of Drying Kinetics of Moroccan Eucalyptus Globulus. Drying Technology, 10(10), 2027-2039.

Lagnaoui, Ahmed (1999): Aux frontières de la tradition marocaine. Casablanca: Editions Toubkal.

Lavenderová, Susan (1999): Magické rostliny, aneb, Byliny od A do Z. Praha: Volvox Globator. 
Levey, Martin (1973): Early Arabic Pharmacology: An Introduction Based on Ancient and Medieval Sources. Leiden: Brill.

Mahdi, Mohamed (1999): Pasteur de l'Atlas. Production pastorale, droit et rituel. Casablanca: Fondation Konrad Adenauer.

Margaris, Nikos S. - Koutsidou, Eugenia - Giourga, Christina (1996): „Changes in Traditional Mediterranean Land Use Systems." In: Mediterranean Desertification and Land Use, edited by C. Jane Brandt and John B. Thornes, 29-42. Chichester: Wiley.

Maselli, Daniel A. (1996): Contraintes d'une utilisation durable des resources naturelles du Haut-Atlas: le cas du bassin intramontagnard de Tagoundaft. Revue de Géographie Alpine, 84(4), 109-119.

Mateo Dieste, Josep Lluís (2013): Health and Ritual in Morocco: Conceptions of the Body and Healing Practices. Leiden: Brill.

Mernissi, Fatima (1987): Beyond the Veil: Male-Female Dynamics in Modern Muslim Society. Bloomington: Indiana University Press.

Moerman, Daniel E. - Jonas, Wayne B. (2002): Deconstructing the Placebo Effect and Finding the Meaning Response. Annals of Internal Medicine, $136,471-476$.

Montanari, Bernadette (2014): Aromatic Medicinal Plants and Vulnerability of Traditional Herbal Knowledge in a Berber Community of the High Atlas Mountains of Morocco. Plant Diversity and Resources, 36(3), 388402.

Moufid, Abderrahmane - Eddouks, Mohamed (2012): Artemisia herba alba: A Popular Plant with Potential Medicinal Properties. Pakistan Journal of Biological Sciences, 15(24), 1152-1159.

Msanda, Fouad - El Aboudi, Ahmed - Peltier, Jean-Paul (2005): Biodiversité et biogéographie de larganeraie marocaine. Cahiers Agricultures, 14(4), 357-364.

Nassif, Fatima - Tanji, Abbes (2013): Gathered Food Plants in Morocco: The Long Forgotten Species in Ethnobotanical Research. Life Sciences Leaflets, 3, 17-54.

Parada, Montse - Carrió, Esperança - Bonet, Maria Àngels et al. (2009): Ethnobotany of the Alt Empordà Region (Catalonia, Iberian Peninsula): Plants Used in Human Traditional Medicine. Journal of Ethnopharmaco$\log y, 124,609-618$.

Parusniková, Zuzana (2000): Biomoc a kult zdraví. Sociologický časopis, 36(2), 131-142.

Paydar, Niloo Imami - Grammet, Ivo (2002): The Fabric of Moroccan Life. Indianapolis: Indianapolis Museum of Art.

Pordié, Laurent - Simonm, Emmanuelle (2013): „Que sont les guérisseurs devenus?" In: Les nouveaux guérisseurs: biographies de thérapeutes au temps de la globalisation, edited by Laurent Pordié and Emmanuelle Simon, 9-35. Paris: Editions de l'École des Hautes Études en Sciences Sociales.

Půtová, Barbora (2016): New Findings on Rock Engravings in the Oukaïmeden Valley (High Atlas, Morocco) and Their Implications to the Local Transhumance. Anthropologia integra, 7(2), 33-46.

Sheldon, Jennie Wood - Balick, Michael J. - Laird, Sarah A. (1997): Medicinal Plants: Can Utilization and Conservation Co-Exist? New York: The New York Botanical Garden.

Sijelmassi, Abdelhaï (1990): Les plantes médicinales du Maroc. Casablanca: Editions Le Fennec.
Slepičková, Lenka - Šlesingerová, Eva - Šmídová, Iva (2012): Biomoc a reprodukční biomedicína: konceptuální inspirace pro česky kontext. Sociologický časopis, 48(1), 85-106.

Stillman, Norman A. (1982): „Saddiq and Marabout in Morocco.“ In: The Sephardi and Oriental Jewish Heritage, edited by Issachar Ben-Ami, 489500. Jerusalem: Magnes Press.

Sullivan, Lawrence Eugene (1989): Healing and Restoring: Health and Medicine in the World's Religious Traditions. New York, London: Macmillan.

Sunlu, Ugur (2003): „Environmental Impacts of Tourism. Options Méditerranéennes." In: Local Resources and Global Trades: Environments and Agriculture in the Mediterranean Region, edited by Laura Grassini, Domenico Camarda, 263-270. Bari: CIHEAM.

Tabbaa, Yasser - Mervin, Sabrina (2014): The Gate of Wisdom. History, Heritage \& Significance of the Holy City of the Shia. Paris: Unesco.

Teixidor-Toneu, Irene - Martin, Gary J. - Ouhammou, Ahmed et al. (2016): An Ethnomedicinal Survey of a Tashelhit-Speaking Community in the High Atlas, Morocco. Journal of Ethnopharmacology, 188, 96-110.

Teixidor-Toneu, Irene -Martin, Gary J. - Puri, Rajindra K. et al. (2017): Treating Infants with Frigg: Linking Disease Eetiologies, Medicinal Plant Use and Care-Seeking Behaviour in Southern Morocco. Journal of Ethnobiology and Ethnomedicine, 13(4): DOI 10.1186/s13002-016-0129-4

Terem, Etty (2014): Old Texts, New Practices: Islamic Reform in Modern Morocco. Stanford: Stanford University Press.

Thurlkill, Mary (2016): Sacred Scents in Early Christianity and Islam. Lanham: Lexington Books.

Turner, W. Victor (1967): The Forest of symbols: Aspects of Ndembu Ritual. New York: Cornell University Press.

Venema, B. - Mguild, A. (2002): The Vitality of Local Political Institutions in the Middle Atlas, Morocco. Ethnology, 41, 103-117.

Westermarck, Edward (1926): Ritual and Belief in Morocco I. London: Macmillan and Co.

Whyte, Susan Reynold - van der Geest, Sjaak - Hardon, Anita (2007): Social Lives of Medicines. Cambridge: Cambridge University Press.

Zarzuelo, Antonio - Crespo, Esperanza (2002): „The Medicinal and Non Medicinal Uses of Thyme." In: Thyme: The Genus Thymus, edited by Elisabeth Stahl-Biskup and Francisco Saez, 263-292. London: Taylor \& Francis.

Zekri, Nadi - Amalich, Smail - Boughdad, Ahmed et al. (2013): Phytochemical Study and Insecticidal Activity of Mentha pulegium. L. Oils From Morocco Against Sitophilus Oryzae. Mediterranean Journal of Chemistry, 2(4), 607-619.

Zenasni, Laila - Bakhy, Khadija - Gaboun, Fatima et al. (2014): Essential Oil Composition and Biomass Productivity of Moroccan Endemic Thymus satureioides Coss. \& Ball. Growing in the Agoundis Valley. Journal of Medicinal Plant Research, 8(12), 504-512.

Zidane, Ahlam - Tits, Monique - Angenot, Luc et al. (2014): Phytochemical Analysis of Tetraclinis articula in Relation to its Vasorelaxant Property. Journal of Materials and Environmental Science, 5(5), 1368-1375.

Ziyyat, Abderrahim - Legssyer, Abdelkhaleq - Mekhfi, Hassane et al. (1997): Phytotherapy of Hypertension and Diabetes in Oriental Morocco. Journal of Ethnopharmacoly, 58, 45-54. 